\title{
Strawberry fields forever? Urban agriculture in developed countries: a review
}

\author{
Hoi-Fei Mok • Virginia G. Williamson • James R. Grove • \\ Kristal Burry • S. Fiona Barker • Andrew J. Hamilton
}

Accepted: 22 April 2013 / Published online: 30 May 2013

(C) The Author(s) 2013. This article is published with open access at Springerlink.com

\begin{abstract}
Food production in cities has long been a tradition in many countries around the world and a mainstream activity for many developed countries. While urban agriculture plays an important role in increasing food security and social well-being, it comes with significant costs and constraints. Here, we review the growth of urban agriculture throughout the developed world in order to clarify the different benefits, risks, and hindrances associated with the practice. Through this analysis, we identify the need for better understanding of the following five aspects if urban agriculture is to make a meaningful contribution to food security and social well-being in the future: (1) the impacts of continued urban sprawl and loss of peri-urban agricultural land; (2) appropriate government and institutional support at local, regional, and country levels; (3) the role of urban agriculture in self-sufficiency of cities; (4) the risks posed by pollutants from agriculture to urban ecosystems and from urban ecosystems to agriculture; and (5) the carbon footprint of urban agriculture and use of "food miles." If urban agriculture is to have a legitimate place in resolving the global food crisis as advocates claim, then it is time to take urban agriculture seriously and assess more rigorously both the positive and negative impacts, especially carbon
\end{abstract}

H.-F. Mok $(\bowtie) \cdot J$. R. Grove $\cdot$ K. Burry $\cdot$ S. F. Barker

Melbourne School of Land and Environment,

The University of Melbourne, Parkville Campus,

221 Bouverie Street, Carlton, Victoria 3010, Australia

e-mail: femok@student.unimelb.edu.au

V. G. Williamson

Melbourne School of Land and Environment,

The University of Melbourne, Burnley Campus,

500 Yarra Boulevard, Richmond, Victoria 3121, Australia

\section{A. J. Hamilton}

Melbourne School of Land and Environment,

The University of Melbourne, Dookie Campus,

940 Dookie-Nalinga Road, Dookie College, Victoria 3647, Australia emissions. Only then can the world's limited resources be properly allocated to the development of urban agriculture.

Keywords City · Food · Garden · High-income country · Horticulture $\cdot$ Vegetable

Contents

1. Introduction . . . . . . . . . . . . . . . . . 3

2. United States of America and Canada .......... 4

2.1. Crises of war and economic depression ......4

2.2. Urban agriculture and the environmental movement ................ 5

2.3. Three scales of urban agriculture $\ldots \ldots \ldots \ldots 6$

2.4. Food policy plans .................. 8

2.5. Vertical farming ................. 9

2.6. Self-sufficiency in cities ............. 10

2.7. Chemical contamination risks . . . . . . . 10

3. United Kingdom ...................... 12

3.1. Commercial agriculture . . . . . . . . . 12

3.2. Subsistence agriculture $\ldots \ldots \ldots \ldots \ldots 13$

3.3. Allotments in contemporary times . . . . . . . 14

3.4. Food policy plans . . . . . . . . . . . 15

3.5. Carbon footprint ................ 16

4. Australia . . . . . . . . . . . . . . . . . 17

4.1. Wartime and post-wartime urban agriculture . 17

4.2. Forms of contemporary urban agriculture . . . 18

4.4. Food policy plans . . . . . . . . . . . . 20

4.5. Water for agriculture in a dry city . . . . . . 21

5. Japan . . . . . . . . . . . . . . . . . . . 22

5.1. Mixed rural-urban landscapes . . . . . . . . 22

5.2. Decline of food self-sufficiency . . . . . . . . 23

5.3. Food policy and local food movements . . . . . 24

5.4. Environmental impacts and public health risks ..................... 25

6. Conclusions ...................... 26 


\section{Introduction}

Food production in cities has long been a tradition in many countries around the world, and in recent decades, urban agriculture has become mainstream in many developed countries. While there are numerous definitions of urban agriculture in the literature (Smit et al. 1996; Mougeot 2000; FAO 2007), here, we focus mainly on horticultural activities within an urban or peri-urban setting, rather than animal husbandry, aquaculture, or arboriculture, since food plant cultivation is the dominant form of urban agriculture. While in some ways the child of the environmental and social justice movements, urban agriculture in developed countries plays a far bigger role than simply satisfying a feel-good niche. In some cities, up to $100 \%$ of certain fruit and vegetables are produced in the urban fringes (ABS 2010, 2011). In addition to the significant contribution to food supplies, the benefits of urban agriculture are numerous and well documented. They include, inter alia, reduced food transportation distance, carbon sequestration, potentially reduced urban heat island effect, improved physical and mental health, improved aesthetics, community building, employment opportunities, improved local land prices, shortened supply chains and, thus, reduced price differentials between producers and consumers, provision of habitat for wildlife, and waste recycling (Brown and Jameton 2000; Slater 2001; Twiss et al. 2003; Hynes and Howe 2004; Pearson et al. 2010).

The future of such urban agricultural activity faces significant challenges, however. With a global shift to predominantly urban populations (UN Population Division 2005; Wimberley et al. 2007) and the relentless encroachment of urbanization into rural landscapes, conflicts between agriculture on the urban fringes and development have increased (Lobao and Meyer 2001; Brown et al. 2005; Millar and Roots 2012). The prospect of shrinking agricultural land near cities is alarming considering the need to maintain food security for growing populations and may necessitate more efficient or intensive production. At the same time, environmental and health risks associated with intensive production, including chemical and microbiological contamination of food, light pollution from greenhouses, and soil contamination, must be considered (Deportes et al. 1995; Bryld 2003; Bell et al. 2011). It has been argued that urban agriculture could, in some circumstances, lead to a substantial net increase in carbon emissions through (1) growing plants locally but in less favorable environments that require additional energy and fertilizer inputs; (2) reducing population density and, thus, necessitating more automobile use; and (3) the necessarily poorer economies of scale attendant with smaller, fragmented systems (McWilliams 2009; Glaeser and Kahn 2010). Governments can play a key role in the successful integration of urban agriculture; food policy plans and high-level political backing can give the needed infrastructure support and legitimacy (Fig. 1), but in other circumstances can be used to hinder the growth of urban food production (Kimura 2011).

Given the significance of urban agriculture around the world, there is a need to thoroughly analyze its potential for developed countries; however, there is to date no review on a global scale. Existing reviews focus primarily on regions or aspects of the developing world (Bryld 2003; De Bon et al. 2010; Eriksen-Hamel and Danso 2010) or are restricted to specific developed countries (Bassett 1981; Hynes and Howe 2004; Budge 2009). Here, we undertake the task of providing an overview of the past and present forms of urban agriculture throughout the developed world; developing countries are considered in an accompanying paper (Hamilton et al. 2013). The scope of the paper thus focuses on the USA, Canada, UK, Australia, and Japan as the developed countries representing major geographical regions across the globe (World Bank 2012).

The stories of urban agriculture in these developed countries, while distinctly shaped by each country's history, share commonalities. Some of these shared themes include the crisis of war or economic depression as a driver of urban agriculture (USA, UK, Australia), the role of government policy in supporting urban agriculture (USA, UK, Australia, Japan), and the risks from urban pollution (USA and Japan). In the following discussion, we attempt to clarify these themes and elucidate the challenges facing urban agriculture as well as its future potential.

\section{United States of America and Canada}

\subsection{Crises of war and economic depression}

Urban agriculture in contemporary North America has its roots in times of crisis. Wartime gardening was promoted as a way to increase food security and patriotism in the USA during World Wars I and II. The War Garden movement was supported through the National War Garden Commission, which launched a series of posters, cookbooks, manuals, poems, and signs in 1917 (Fig. 2) to encourage civilians at home to enter the war effort through growing food (Pack 1919). Serious food shortages were occurring in Europe during World War I due to various factors, including prewar crop failures, dependence on imported food, and the decision to divert increasing amounts to feed Allied troops (Perren 2005). Britain, France, Italy, and Belgium could count on only $60 \%$ of their normal wheat production by 1917 , and as the war continued, meat and cereals were heavily rationed (Wright 1942). The Allied forces' food shortages were alleviated by the United States' food exports during the war, an effort made possible by voluntary food 
Fig. 1 First Lady of the United States of America, Michelle Obama, leading by example with the establishment of a vegetable garden in the grounds of The White House,

Washington, DC. .Photograph courtesy of The White House/ Joyce N. Boghosian.

Reproduced under Public Domain

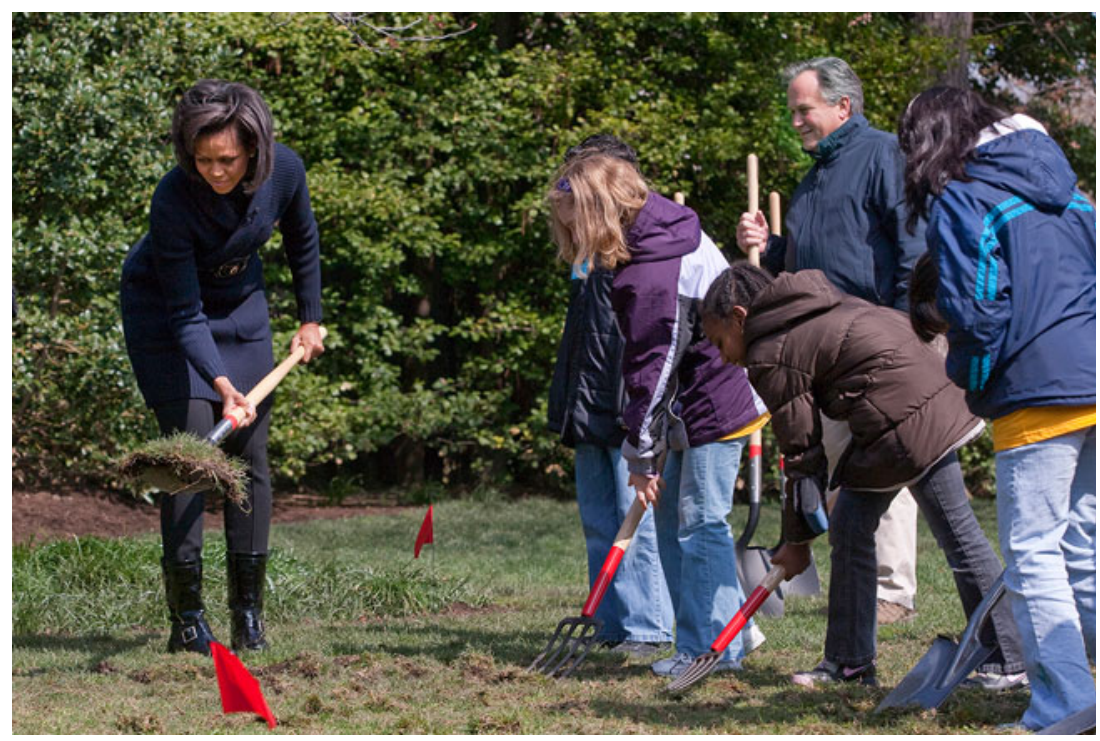

conservation measures and reliance on war gardens by American civilians. The National War Garden Commission counted 3.5 million war gardens producing US \$350 million worth of food in 1917 and 5.3 million war gardens producing US \$525 million worth of food the following year, liberating significant commercial agricultural production that could be shipped overseas (Pack 1919).

North Americans continued to rely on gardening through the Great Depression of the 1930s. These Relief Gardens, both individual plots and larger-scale industrial plots, provided food, income, and purpose to thousands of unemployed (Bassett 1981). With the emergence of Victory Gardens in World War II, gardens similar to the War Gardens of World War I, the focus of backyard food production shifted from maintenance of self-respect and independence to American patriotism and a strong association between gardening and the language of war. Similar to the National War Garden Commission, the National Victory Garden Program, which was supported by the War Food Administration, ran propaganda to associate gardening with patriotism, civic responsibility, and dignity (Fig. 2). These gardens helped lessen demand on commercial food supplies and strategic materials used in food processing and canning, freeing up supplies for the Armed Forces and, in turn, railway carriers through reduced food transportation (Bassett 1981). They also maintained morale and improved food security in case of severe shortages (Bassett 1981). The active propaganda associated with both War and Victory Gardens was highly successful; in 1944, the
Fig. 2 US government $\mathrm{War}$ and Victory Garden propaganda posters from World War I (left) and World War II (right), respectively. Images reproduced under Public Domain

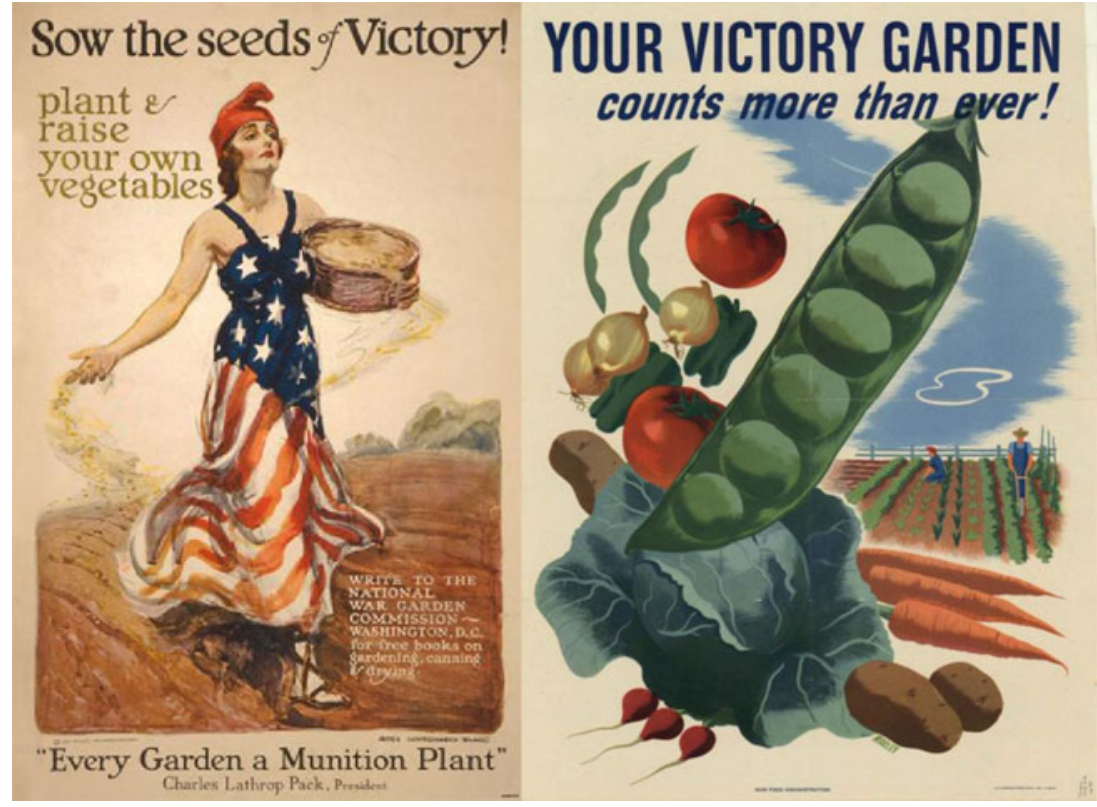


peak of production, 20 million Victory Gardens in the USA accounted for $40 \%$ of the nation's fresh vegetables (Bassett 1981).

\subsection{Urban agriculture and the environmental movement}

After the wars, reduced food demand, along with the advent of convenient neighborhood supermarkets and refrigeration, made backyard food production unnecessary, and families were encouraged to embrace consumerist lifestyles as the new way to assert democracy and equality (Press and Arnould 2011). It was not until the late 1960s and early 1970s that interest in community and backyard gardens reappeared. Growing environmental awareness and the counter-culture movement against consumerism, conformity, and industry, as well as inflation and unemployment, motivated people ideologically and economically to cultivate their own food for the decades that followed (Bassett 1981; Hynes and Howe 2004; Press and Arnould 2011). In more recent times, books such as Omnivore's Dilemma (Pollan 2006) and Fast Food Nation (Schlosser 2001) and documentaries such as Food, Inc. (Kenner 2008) have not only given mainstream audiences compelling critiques of the industrial agricultural system but also popularized alternative production methods. Urban agriculture, from growing one's own food to buying locally, has become integrated into an ideological movement of environmentally and socially sustainable choices, community networks, reconnections with nature, and social change in North America (Follett 2009; Press and Arnould 2011).

\subsection{Three scales of urban agriculture}

Three different scales of urban agriculture are present in the USA and Canada, namely, small commercial farms and community-supported agriculture (CSA), community gardens, and backyard gardens, with some initiatives representing a hybrid of two or more of these (Brown and Carter 2003). The United States Department of Agriculture (USDA) defines small farms as those which generate less than US $\$ 250,000$ in gross sales (Brown and Carter 2003). Many of these are urban farmers who sell their products directly through farm stands and farmers' markets, with the largest direct sales occurring in California, New York, Pennsylvania, Michigan, and Ohio (Timmons and Wang 2010). Both farmers' markets and CSA programs, where members join and receive a share of the local harvest for an annual membership fee, have become increasingly popular: the number of farmers' markets has increased almost $50 \%$ since 1994, and the number of CSAs has grown from over 1,700 in 2005 to over 12,500 in 2007 (Brown and Carter 2003; USDA 2009; Press and Arnould 2011).

Community gardens comprise large lots of land subdivided into plots for individual households and can be owned by a municipality, institution, community group, or land trust (Brown and Carter 2003). The Urban Gardening Program, established by Congress in 1977, provided annual grants of US $\$ 150,000-250,000$ through the Cooperative Extension Service for such gardens (Brown and Jameton 2000; Hynes and Howe 2004). The program grew from 6 to 23 cities by 1993, when funding for the program was discontinued due to lack of support from the USDA and the Cooperative Extension Service (Malakoff 2004). Despite this, the community gardens movement has continued to expand across the USA, and in 2009, the USDA started a new initiative, called The People's Garden, to promote community gardening (USDA 2010). Today, the American Community Gardening Association estimates that there are over 18,000 community gardens in the USA and Canada, ranging from neighborhood gardens to public housing gardens and school gardens (MunroeSantos 1998; Kortright and Wakefield 2011).

Community gardens have become a way to combat food insecurity. In 2009, the US Census reported that 43.6 million people in the USA were living in poverty (US Census Bureau 2010) and that even when cash was available, food was not always accessible. This problem has been given much attention recently, with media stories highlighting how transportation to supermarkets is difficult for inner city residents without cars and how fresh produce at such inner city food markets is expensive (De Vries and Heyboer 2011; Economist 2011). The term "food desert," an area characterized by poor access to healthy and affordable food through lack of physical ability, financial means, or knowledge, has been widely used in the last two decades to describe the phenomenon (Shaw 2006). Food deserts are not unique to the USA, but the literature for the American food system is most abundant (Beaulac et al. 2009). Much research has documented the lack of access to supermarkets, racial/ethnic and socioeconomic disparities in food access, differences in chain versus non-chain stores, cost of food, availability of particular food items, and links to obesity (Franco et al. 2008; Larson et al. 2009; Schafft et al. 2009; Walker et al. 2010; D'Angelo et al. 2011). The findings point to a trend of low-income and ethnic minority neighborhoods in the USA facing more barriers to accessing healthy and affordable food (Walker et al. 2010). Non-profit organizations and government agencies, such as the Homeless Garden Project in Santa Cruz, California, Just Food in New York City, and FoodShare in Toronto, Canada, work with community gardens and CSA farms to encourage food production and to distribute food to those in need (Brown and Carter 2003; Saldivar-Tanaka and Krasny 2004; Johnston and Baker 2005). In addition to supplementing food budgets and promoting healthy eating and exercise, community gardens also serve as communal spaces that facilitate neighborhood gatherings and exchanges across generations and cultures, societal development, and empowerment (Hynes and Howe 2004; 
Saldivar-Tanaka and Krasny 2004). Members of community gardens often report a number of personal and social benefits, such as improved mental health, spiritual connection, and community belongingness (Okvat and Zautra 2011; Turner 2011).

Backyard food gardening represents the smallest scale of urban agriculture, with food produced around the home, including balconies, rooftops, and decks (Brown and Carter 2003). Backyard food gardeners are motivated by different factors, with a study of 125 residents in two Toronto neighborhoods reporting motivations including cooking with fresh ingredients, teaching children about nature, environmental sustainability, connecting to cultural or past identity, aesthetics, personal hobby, and neighborhood exchange (Kortright and Wakefield 2011). As with community gardens, backyard gardens influence food security through improved accessibility, affordability, and selfreliance (Kortright and Wakefield 2011).

Rooftop food production is a more recent addition to the mix of urban food production systems in North America. While still very much a novelty, there are both commercialscale and community-focused projects in existence, as well as household-scale rooftop gardens (Engelhard 2010; Nasr et al. 2010). In May 2009, Toronto passed a bylaw requiring green roofs to be installed on new commercial, institutional, and residential developments (City of Toronto 2012), and while not specifically addressing the issue of rooftop agriculture, it listed "opportunities for local food production" as one of the many environmental benefits. There are various plans for large-scale rooftop food production, such as the recently announced Brooklyn project, which will entail a $100,000-\mathrm{ft}^{2}$ hydroponic greenhouse, making it the largest rooftop farm in the world (BrightFarms 2012). However, there is little literature on green roofs and food production. Most research has focused on thermal and energy benefits, reduction of storm water runoff, biodiversity impacts, and amelioration of air pollution (Theodosiou 2003; Wong et al. 2003; VanWoert et al. 2005; Getter and Rowe 2006; Mentens et al. 2006; Oberndorfer et al. 2007). This gap in knowledge may be attributable to the difficulty in implementing intensive horticultural production on roofs. Due to the high cost of installation, significant ongoing maintenance, and building weight restrictions, most green roofs are extensive, shallow-substrate roofs rather than deeper, intensive roofs (Getter and Rowe 2006; Oberndorfer et al. 2007). In extensive green roofs, plant species are typically restricted to those that are drought-tolerant and shallow-rooted, minimizing both irrigation and depth of planting media to limit weight. The rooftop environment can provide challenging growing conditions with high levels of solar radiation, chemical exhaust from automobiles or industrial infrastructure, strong winds, and extreme temperatures, further necessitating the selection of hardy plant species (Getter and Rowe 2006). While native species are often touted as the best choice by landscape designers, research directly comparing native and nonnative survival on green roofs showed that place of origin may not be the best criterion for plant selection (Butler et al. 2012). In addition, practical matters such as difficulty in harvesting crops and a lack of guidelines on implementation can deter the use of green roofs for food production.

\subsection{Food policy plans}

In addition to leadership in green roofs, Toronto has been a pioneer of food security policy and advocacy. The City of Toronto's Food and Hunger Action Committee was established in December 1999 to study food security in Toronto and to recommend methods to reduce hunger, improve health and nutrition, and to support food-based initiatives (Food and Hunger Action Committee 2003). Among the initiatives that the Toronto City Council committed to in 2001 were the Toronto Food Charter-an agreement to promote food safety programs and services, protect local agricultural lands, encourage community gardens, and other goals - and The Growing Season, an action plan outlining steps to take to achieve these goals (Food and Hunger Action Committee 2003). The Canadian national government has also shown commitment and support for local food production. In 2011, a national food policy plan, known as the People's Food Policy, was produced, which included a recommendation to increase and strengthen local food production, such as through urban agricultural activities (People's Food Policy Project 2011).

The USA has a number of food-related initiatives in addition to The People's Garden. In 2009, First Lady Michelle Obama established the first vegetable garden at The White House since Eleanor Roosevelt's Victory Garden, giving the urban agriculture movement additional momentum and legitimacy. Michelle Obama has shown further leadership in addressing issues related to nutrition and childhood obesity through the foundation of the Let's Move initiative in 2010, which promotes healthy eating and gardening at home, school, and in the community (Let's Move 2012). At a system level, the Know Your Farmer, Know Your Food initiative was started in 2009, providing infrastructure which helps local food producers move into mainstream markets and clarifies regulatory uncertainties (USDA 2012). This initiative aims to connect farmers with consumers as well as support local and regional food groups. The USA has long had national food policies in the form of the farm bill, a comprehensive bill that addresses a number of agricultural and food issues such as international trade, rural development, conservation, research, food safety, nutrition programs, and subsidy programs. This legislation is passed every 5 years or so by the Congress, and 
the latest farm bill is due for a vote later in 2013 (American Farmland Trust 2012).

\subsection{Vertical farming}

An interesting technological concept in relation to the future of urban agriculture from the USA is vertical farming, sometimes called sky farming. Vertical farming is based on the concept that the most efficient growing conditions can be built around the crop rather than trying to adapt to the natural environment, eliminating the degradation that often accompanies the pursuit of ever higher crop yields. The current ideas and concepts surrounding vertical farming are primarily championed by Professor Dickson Despommier at Columbia University in New York (Despommier 2010), though other countries have expressed interest in the idea. While there are many web sites that cover conceptual designs (Urban Ecological Systems 2007; Vertical Farm 2012) and public interest stories (Venkataraman 2008; Graham-Rowe 2010; Kretschmer and Kollenberg 2011), there is, to our knowledge, only one peer-reviewed article, by Germer et al. (2011), that deals with rationalizing the technical advantages and constraints of the current concepts.

Germer et al. (2011) neatly provide a platform of discussion based around the possibilities of sky farming rice crops. The main constraints to reach production and sustainability objectives are lack of water and nutrients, insufficient insolation, temperature and humidity deviation, pest prevalence, and unstable energy supply. It is suggested that there is potential for LED lighting systems, in combination with architectural design and housing plant life stages in optimum conditions, to provide sufficient lighting. The conceived aeroponic system would provide a mist of both nutrients and water that reduces weight loading issues from soil or hydroponic systems. However, the resulting humidity would need to be managed to avoid condensation and potential fungal diseases through a sterile and hermetically sealed environment at all stages. The approach of Germer et al. (2011) focuses on optimizing the energy and nutrient requirements for conventional rice crops. There may be fixes for some of the identified technological limitations through genetic modifications, such as rice crops designed to be grown in aeroponic environments that need minimal humidity and have leaf surfaces that minimize fungal growth. Despite these considerations, there remains a large gap in the assessment of economic viability, with the need for a whole-life cost analysis to be undertaken. Life cycle analysis (LCA) will also be necessary to address the environmental externalities, such as embodied carbon emissions and water usage in the concrete used for the buildings, energy costs for the lighting, and loss of agroecosystem services. As stated in a Nature book review of Despommier's The Vertical Farm, “... if Despommier won't do the math, someone should. Any idea that might help us to avoid displacing any more natural areas with agriculture deserves a hearing" (Marris 2010).

\subsection{Self-sufficiency in cities}

An important debate within the urban agriculture movement is what level of self-sufficiency cities can realistically obtain. Local self-sufficiency or reliance refers to the principle that localities should have the capacity to produce or obtain at least the basic necessities from within their physical boundaries (Morris 1987). It can be argued that in this modern age of globalization, it is impractical to be completely isolated, with many benefits associated with sharing knowledge and resources globally. However, basic needs such as food and water should still be essential items that a community can gain access to for the sake of economic stability, autonomy, and survival, especially in light of environmental and climatic changes. In the case of urban agriculture, self-reliance means the ability to produce enough food for people living in an urban area, be it a household, neighborhood, city, or region, without relying on external resources. Such local self-reliance comes with a number of economic and social benefits, including job creation within the food sector, increased property values, reduced economic leakage, and community empowerment (Malakoff 2004).

Despite the importance of self-sufficiency for cities, there is little literature on food self-reliance in urban areas. Grewal and Grewal (2012) cover a quantitative assessment of the potential level of food self-reliance for the city of Cleveland, Ohio. Using a simple formula of vacant land area multiplied by yield divided by intake, the authors calculated the percentage of self-reliance for vegetables, fruits, poultry, eggs, and honey for different scenarios of land usage in Cleveland. As shown in Table 1, under a scenario that uses $80 \%$ of every vacant lot, between 22 and $48 \%$ of Cleveland's demand for fresh produce (vegetables and fruit) could be met, depending on the cultivation technique (conventional gardening, intensive gardening, hydroponics; Grewal and Grewal 2012). Inclusion of $62 \%$ of every industrial and commercial rooftop as well as $9 \%$ of every occupied residential lot pushes potential self-reliance to 46-100\% of fresh produce demands (Table 1). While these numbers are promising for horticultural production, even the third and most intensive scenario would not be nearly enough to satisfy the average American adult diet (Table 1), which consists primarily of grains and protein (Sebastian et al. 2011). As discussed in the accompanying publication on urban agriculture in developing countries, the amount of land currently used for global cereal production is approximately ten times the land occupied by cities worldwide, whereas global vegetable and fruit production each cover an area roughly equivalent to that of cities (Hamilton et al. 2013). However, demonstration of the feasibility of meeting demands for fresh produce through local production is highly significant, particularly when climate-driven crop failures 
Table 1 Percentage self-reliance in fresh vegetables, fresh fruit, shell eggs, poultry, and total food and beverage in Cleveland, Ohio, under three different scenarios and using three vegetable production practices: conventional, intensive, and hydroponic (Grewal and Grewal 2012)

\begin{tabular}{|c|c|c|c|c|c|c|c|c|c|}
\hline & \multicolumn{3}{|c|}{ Scenario $1^{\mathrm{a}}$} & \multicolumn{3}{|c|}{ Scenario $2^{\mathrm{a}}$} & \multicolumn{3}{|c|}{ Scenario $3^{\mathrm{a}}$} \\
\hline & $\mathrm{C}$ & I & $\mathrm{H}$ & $\mathrm{C}$ & I & $\mathrm{H}$ & $\mathrm{C}$ & I & $\mathrm{H}$ \\
\hline Fresh vegetables ${ }^{\mathrm{b}}$ & 22 & 41 & 48 & 31 & 58 & 68 & 46 & 85 & 100 \\
\hline Fresh fruits ${ }^{\mathrm{b}}$ & 22 & 41 & 48 & 31 & 58 & 68 & 46 & 85 & 100 \\
\hline Shell eggs ${ }^{c}$ & 25 & 25 & 25 & 94 & 94 & 94 & 94 & 94 & 94 \\
\hline Poultry & 25 & 25 & 25 & 94 & 94 & 94 & 94 & 94 & 94 \\
\hline Total food and beverage ${ }^{\mathrm{d}}$ & 4.2 & 6.4 & 7.4 & 9.3 & 12.6 & 13.8 & 11.1 & 15.9 & 17.7 \\
\hline Total food and beverage ${ }^{\mathrm{e}}$ & 1.8 & 2.7 & 3.0 & 4.3 & 5.5 & 5.9 & 4.9 & 6.6 & 7.3 \\
\hline
\end{tabular}

$C$ conventional, $I$ intensive, $H$ hydroponic

${ }^{a}$ Scenario $1: 78.5 \%$ of every vacant lot $(80 \times 80$-ft garden $)$ dedicated to vegetables and fruit and $1.5 \%$ of every vacant lot $(11 \times 11-\mathrm{ft}$ chicken coop and run) used for eggs and poultry. Scenario 2 : scenario 1 plus an additional $7.2 \%$ of every occupied residential lot (20×20-ft garden) used for vegetables and fruit and $1.8 \%$ of every occupied residential lot $(10 \times 10-\mathrm{ft}$ chicken coop and run) used for eggs and poultry. Scenario 3 : scenario 2 plus $62 \%$ of every industrial and commercial rooftop used for vegetables and fruit

${ }^{\mathrm{b}}$ These categories represent only those vegetables and fruits that can be produced in Ohio (see Grewal and Grewal 2012 for a complete list)

${ }^{\mathrm{c}}$ Given current zoning codes limiting the number of chickens per lot for maximum production

${ }^{\mathrm{d}}$ Total food and beverage percent self-reliance was calculated based on total weight

${ }^{\mathrm{e}}$ Total food and beverage percent self-reliance was calculated based on total expenditure

are likely to increase dependence on agricultural imports (Fischer et al. 2005; Schlenker and Roberts 2009).

\subsection{Chemical contamination risks}

Among the challenges associated with increased urban food production are health risks from food contamination. Heavy metals can be introduced into the soil through atmospheric deposition from urban combustion emissions or industrial pollutants (Chen et al. 1997), wastewater usage (Mapanda et al. 2005), and soil amendments that contain agrochemicals or sewage sludge (Deportes et al. 1995; Senesi et al. 1999). These heavy metals may then be bioavailable for plant uptake and consequent human consumption (Kachenko and Singh 2006). The routes most common in developed countries are urban combustion emissions and industrial pollutants. Accumulation of trace metals in vegetation grown near roads has been shown to be significantly higher than those grown in rural areas due to traffic-related contaminants in the air (Chen et al. 1997; Hough et al. 2004; Bell et al. 2011; Saumel et al. 2012). Such metal accumulation in edibles could pose a hazard to human health in terms of cancer incidence and mortality due to low toxic threshold concentrations or bioavailability (Senesi et al. 1999). While the majority of foods grown in urban areas pose minimal risk, if grown in close proximity to roads, the risks will be elevated, especially for vulnerable groups such as the elderly and the young (Hough et al. 2004).

Even if gardens are situated away from high-traffic roads, there are risks from historical soil contamination, especially if the sites are on rehabilitated industrial areas, commonly known as brownfields (Kachenko and Singh 2006; US EPA 2011). Contaminants can range from heavy metals, pesticides/herbicides, asbestos, petroleum products, and solvents (Boulding and Ginn 2004). While there are several methods available to deal with such contaminants, the best management practices implemented in the USA and Canada involve rigorous site assessment, monitoring and isolation, bioremediation, capping, and off-site disposal (De Sousa 2003; Boulding and Ginn 2004). The United States Environmental Protection Agency's guideline for safe gardening practices on brownfields encourages gardeners to identify the site's previous history and to either conduct basic or rigorous soil sampling based on the possible risks (US EPA 2011). While there are regulations on cleaning up contaminated lands, the remediation process is expensive and developers are more responsive to economic incentives (Alberini et al. 2005). But studies of two American cities have found that brownfields are disproportionally located in impoverished or minority neighborhoods (Litt and Burke 2002; Lee and Mohai 2011). This may contribute to lack of incentive to redevelop these brownfields, exposing these communities to environmental risks, including consumption of food produced on contaminated soils.

Plant metal uptake depends greatly on the type of plant grown, the metal in question, and the soil conditions (PilonSmits 2005). Over 400 plants, including some edibles, have metal hyperaccumulation abilities, some specific to one metal and others adapted for more general metal accumulation (Prasad and Freitas 2003), while other plant species exclude metals as their metal adaptation strategy (Baker 1981). The bioavailability of metals is influenced by a 
number of factors, including soil $\mathrm{pH}$, metal chelators, and the percentage available in the soluble or exchangeable fraction (Lai and Chen 2004; Munn et al. 2008; PeraltaVidea et al. 2009; Mok et al. 2013). There is much peerreviewed literature on metal phytoextraction, including extensive reviews of the biochemical mechanisms for metal uptake by plants (Lasat 2002; Pilon-Smits 2005), the possible transfers up the food chain (Peralta-Videa et al. 2009), and the diversity of metal-hyperaccumulating plants (Prasad and Freitas 2003). The risks posed by heavy metals vary with the metal toxicity and mobility, with the highest risks for direct ingestion of contaminated soils, but generally, heavy metal accumulation is a long-term issue (Wuana and Okieimen 2011).

\section{United Kingdom}

\subsection{Commercial agriculture}

In terms of production, commercial farms account for the overwhelming majority of food grown in London. According to the 2009 June Survey of Agriculture and Horticulture in England (DEFRA 2010), there are 11,760 ha of commercial farmland in Greater London. The vast majority (94\%) is devoted to grazing (including "setaside" or non-productive uses), farmed woodland, and nonhorticultural arable crops, with horticultural production accounting for $<6 \%$ of the total farmed area. The spread of commercial farming across the three statistical divisions used in the survey is fairly even, from 3,304 ha in West Inner and Outer London to 4,515 ha in South Outer London.

Despite the relatively small total acreage of horticultural production, it is a very intensive and high-value agricultural activity that deserves special consideration. The Lower Lea Valley is the heart of commercial horticulture in London. Straddling the northeastern boundary of Greater London, it has hosted market gardens since the eighteenth century (Garnett 1999a). Originally, most production occurred outdoors, but glasshouses became a more prominent feature of the landscape in the early nineteenth century and particularly so after 1845 , when a tax on plate glass was lifted. Agriculture in the Valley today takes place almost entirely in glasshouses, and most of it is hydroponic (Garnett 1999a). These glasshouses are well known for the production of not only ornamental flowers but also vegetables, especially cucumbers, of which it produces about three quarters of England's total consumption-about 80 million per year (Anon 2011)! It is not only the number of cucumbers that makes the region notable but also their quality: they are said to be juicier, less bitter, and thinner skinned than those from elsewhere in the EU (Anon 2011). The Lea Valley Growers' Association believes that their product is so culturally significant that in 2011, it applied for Protected Geographical Area Indication labeling, which would mean that a cucumber from the region would officially be called a "Lea Valley cucumber" and thus enjoy the same nomenclatural protection and privilege as a select group of foods, including the likes of the Cornish pasty, Champagne, and Camembert cheese. Cucumber growers numerically dominate the Lea Valley, followed by ornamental flower growers (Reading Agricultural Consultants 2003). Tomatoes were once the most significant crop in the district, with production receiving a major boost in World War II when a ban on growing flowers and luxury foods was instigated (Garnett 1999a). But today, tomato production has virtually disappeared from the Valley (Reading Agricultural Consultants 2003). The region has also been, and continues to be, a steady supplier of peppers to London (Garnett 1999a; Reading Agricultural Consultants 2003). The total area under glass in the Lea Valley reached a peak of 530 ha around 1950 and was reported to have declined to around 120 ha by the late 1990s (Garnett 1999a). This reflects a more general trend where, unable to compete with more lucrative land uses in a sprawling city, commercial horticulture in Greater London has been experiencing a steady decline (Fig. 3).

\subsection{Subsistence agriculture}

Agriculture in London extends well beyond commercial enterprises: the city is characterized by a long association

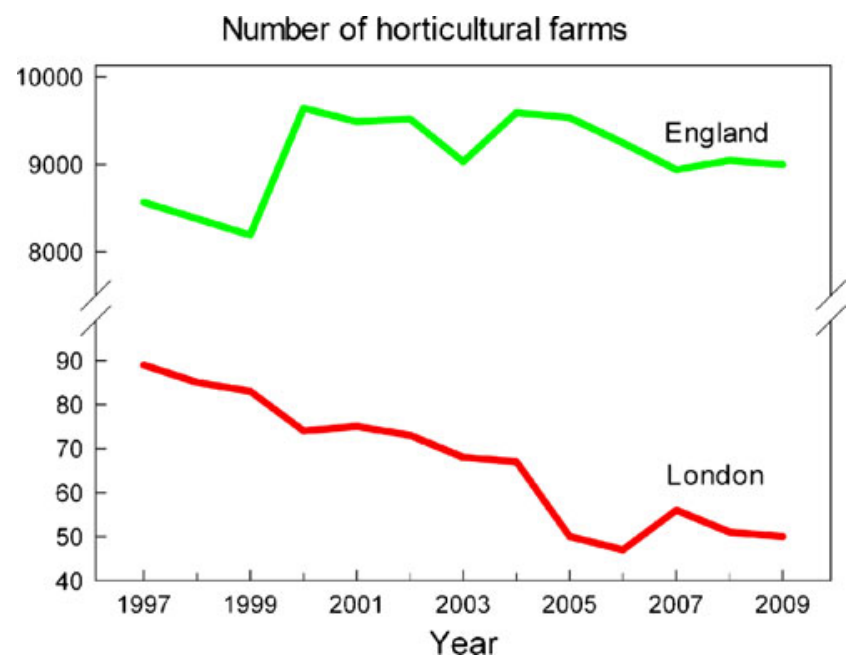

Fig. 3 Number of horticultural farms in England and London. Data are from the 2009 June Survey (DEFRA 2010). Farm size thresholds for inclusion are as follows: permanent outdoor crops (e.g., orchards and vineyards), >1 ha; outdoor intensive production (e.g., vegetables, melons, and strawberries), $>0.5$ ha; mushrooms, $>0$ ha. Note that the DEFRA changed their methodology for the most recent (2010) survey, including substantial increases in the minimum farm size; this has had a marked influence on the number of farms reported, and hence the most recent June Survey data are not presented 
with subsistence production, which is currently being reinvigorated through a strong public interest in food, particularly for health and sustainability benefits. London's subsistence agriculture takes on a variety of guises, including allotments, city farms, community gardens, private gardens, school gardens, and public parks (Garnett 1999a). City farms and community gardens can be found throughout the UK and are mostly used for the keeping of livestock, but individual and shared horticultural plots are also common. Most city farms have been established as teaching facilities designed to give city residents an understanding of and exposure to agriculture, and about $10 \%$ of London's population visit these farms every year (Garnett 1999b). While the total area of private gardens in London is considerable - almost $20 \%$ of the total area of Greater London (Dawson and Worrell 1992) - it is not known what proportion of this area is devoted to food production. School gardens produce very little because their intended purpose is education (Garnett 1999a). Similarly, negligible production takes place in public parks, although there are a few food production plots in London parks (Garnett 1999a).

Allotments are undoubtedly the most common, and indeed charismatic, form of subsistence agriculture in London. The term "allotment" first started to appear in Elizabethan times when small parcels of land were given as compensation to peasants who, owing to the greedy acquisition of common lands by wealthy landlords, no longer had anywhere to produce food (Garnett 1999a; Allotment.org.uk 2012). Allotments assumed an important role with the onset of the Industrial Revolution following the massive influx of the rural poor into cities (Garnett 1999a). Allotment production was revitalized again during World Wars I and II as part of the government's general strategy to increase food selfsufficiency. The German U-boat campaign of WWI took its toll on merchant ships, and food shortages increased the demand for allotments. Many were established on land adjacent to railway lines, and indeed many railway workers were given allotments (Allotment.org.uk 2012). Allotments probably played only a minor role in increasing food security in WWI, and the government's major strategy was to use the labor of the Women's Land Army and the Conscientious Objectors to cultivate conventional farmland; even this needed to be supplemented with a strict rationing program. There was no equivalent of the USA's War Garden campaign of WWI, which actively promoted selfsufficiency at the household scale. This changed during WWII, though, with the launch of the Dig for Victory campaign in 1939. Like its sister Victory Garden promotion across the Atlantic, the purpose of this initiative was to aid the war effort by increasing food security and lessening the demand on commercial food supplies and transportation, especially ships, and to boost national morale. Allotments played a major role in the Dig for Victory campaign, and by
1944 , they were providing about $10 \%$ of the nation's food by weight and about half of its fruit and vegetables (Crouch and Ward 2003). The post-war years were not so kind to allotments though, with many being replaced with residential and industrial developments needed for a burgeoning population.

\subsection{Allotments in contemporary times}

Three types of land tenure arrangements apply to allotments in London today. Statutory allotments, by far the most common, are situated on borough land that has been acquired or appropriated by a council for the specific intent of gardening (London Assembly 2006). These sites are afforded significant protection - in theory at least — and several conditions must be satisfied before they can be sold or used for other purposes (London Assembly 2006). Temporary allotments, on the other hand, are hosted on council land that is allocated for other uses and receive little protection from disposal. The Small Holdings and Allotments Act 1908 (and subsequent related legislation) places a duty on boroughs in England and Wales to provide a sufficient number of plots for their constituents, but no such obligation applies to the boroughs of Inner London. There are also allotments on privately owned land, and these have equivalent legal standing to temporary allotments.

Plots are usually $253 \mathrm{~m}^{2}$ (owing to the historical allocation of ten rods of land) and the average annual rent is around $£ 50-60$, although it has been reported to range from $£ 10$ to $£ 140$ (London Assembly 2006). Generally, produce from an allotment plot cannot be sold unless the profit is destined for the allotment community. Major censuses of England's allotments were undertaken in 1997 (NSALG and APU 1997) and 2006 (London Assembly 2006). The 2006 census identified 737 allotment sites (statutory, temporary, and private) across Greater London's 33 boroughs, with Outer London hosting the majority (Fig. 4). Plot-level information was not attained for all boroughs, but of the 20 for which it was, there were 20,786 plots. A notable decline in allotment provision occurred between the two surveys: (1) the number of sites decreased by 32 (39 were closed and seven were established); (2) the number of plots fell by 1,534 (in the 20 boroughs for which plot data existed); and (3) there was anecdotal evidence that average plot size decreased as a result of some boroughs, such as Wandsworth and Greenwich, splitting plots to meet the demands of long waiting lists. Of the 39 sites that were closed over the decade, it is important to note that several of these had statutory tenure (London Assembly 2006). For example, in 2005 , five applications were made to dispose of statutory sites and all were approved (London Assembly 2006).

Concomitant with the decline in plot provision has been an increase in demand, with waiting lists for plots growing

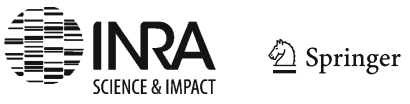


Fig. 4 Number of allotment sites per borough in Greater London. Data from London Assembly (2006)

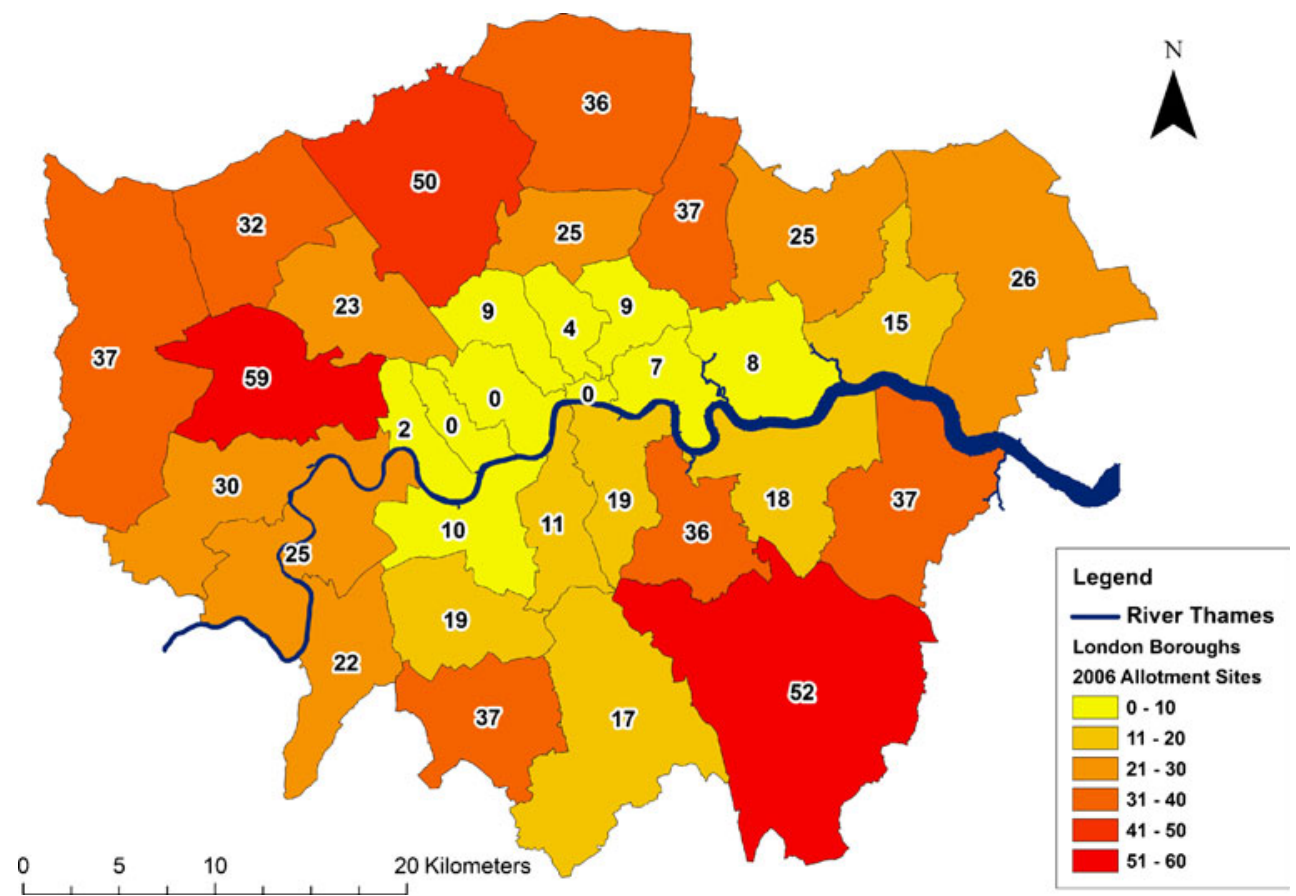

from 1,330 people in 1997 to 4,300 in 2006. The length of waiting lists in Greater London has skyrocketed since 2006, with council surveys in 2010 and 2011 revealing that 16,517 and 16,655 people, respectively, were registered for plots and that 12 boroughs were not accepting new applicants in either year (determined from online databases cited in London Assembly 2006; no data were available for three and five of Greater London's 33 boroughs in 2010 and 2011, respectively). The legislation associated with allotment provision is complex (London Assembly 2006), but the fact that demand for allotments is high (or, indeed, simply that it exists) must raise the question as to whether some boroughs are breaching their statutory duties (Campbell and Campbell 2011). Furthermore, a significant threat to allotments emerged in early 2011 when this 103-year-old obligation for councils to provide allotments to meet demand was targeted in a cull of "burdensome legislation" that local authorities had to contend with (Merrick and Jewsbury 2011). A campaign to protect the legislation was mounted, enlisting numerous food and gardening celebrities, and its success was confirmed when Prime Minister Cameron gave it his backing in the House of Commons (Merrick and Hickman 2011).

\subsection{Food policy plans}

Government support for urban agriculture in London has been mixed. As Executive of the Greater London Authority, the policies of the Mayor of London are important in setting the prominence and direction of urban agriculture in development planning for Greater London. Mayor Ken Livingston released his Food Strategy for London in 2006 (Mayor of London
2006), but agriculture was notably absent: "While farming remains an important consideration for London, this strategy is explicitly and predominantly a food strategy." In fairness, the Food Strategy noted that the London Plan (Mayor of London 2004), released in 2004, was the appropriate planning document, and urban agriculture did receive specific representation in this plan (Policy 3D.14 Agriculture in London). However, the London Plan underwent a full revision following the election of Mayor Boris Johnson to office in 2008 (Mayor of London 2011). The London Assembly scrutinized the Mayor's draft Plan and provided a list of ten recommended amendments/additions relating to urban agriculture (London Assembly 2010). Some of these were taken on board, and the policy directly relating to urban agriculture in the revised London Plan is Policy 7.22 Land for Food, which states that (1) the Mayor will encourage "thriving farming and landbased sectors in London" and (2) "the use of land for growing food will be encouraged nearer to urban communities via such mechanisms as Capital Growth."

Capital Growth is an initiative of London Food Link, a sustainable food network, and is supported by Mayor Johnson and his food adviser, Rosie Boycott. It was launched in 2008 with funding through the London Development Agency with the distinct objective to turn 2,012 parcels of land in Greater London into community food gardens by the end of 2012 (Capital Growth 2012). The goal was achieved - just! - and the count as of 4 April 2013 is 2,024. The program is supported by the Local Food program of the Big Lottery Fund, a philanthropic arm of The National Lottery, and is coordinated by London Food Link, a network of organizations and individuals committed to developing a sustainable food 
system for London. While it could be argued that urban agriculture has not received the representation it should have in important strategic planning documents, it is probably fair to say that London is a leader of such local food initiatives. Of particular note, and complementing the activities of London Food Link and the Mayoral Food Board, is Landshare. The brainchild of celebrity chef Hugh Fearnley-Whittingstall, Landshare was launched in 2009 with the stated purpose of "connecting those who have land to share with those who need land for cultivating food" (Landshare 2012). Landshare recently expanded its domain to Australia and Canada and has started listing allotment sites on the London branch.

\subsection{Carbon footprint}

The carbon footprint of urban agriculture and use of food miles as the emissions indicator is hotly contested (Blanke and Burdick 2005; Edwards-Jones et al. 2008; Rama and Lawrence 2008; Saunders and Barber 2008). Proponents argue that reduced food miles will result in fewer emissions by reducing transportation costs (Paxton 1994). But in some circumstances, urban agriculture may lead to a net increase in carbon emissions through additional energy and fertilizer inputs for plant growth in unfavorable environments, such as with tomatoes grown in Spain and transported to the UK versus tomatoes grown in heated greenhouses in the UK (DEFRA 2008). In fact, returning briefly to the USA, the only comprehensive LCA to date for an entire food system revealed that food miles account for a mere $4 \%$ of the greenhouse gas emissions of the USA's food system, which led the authors to the conclusion that buying local has negligible impact on reducing greenhouse gas emissions and may indeed lead to an increase given the significant contribution of the production phase $(83 \%$; Weber and Matthews 2008).

Estimating greenhouse gas emissions from transport, while superficially simple, actually involves much uncertainty. Attributing the entire transportation emission cost to food is inaccurate if food commodities are shipped with other non-food cargo (Rama and Lawrence 2008). Air freight of horticultural products from Africa to Europe is a particularly interesting situation because the produce is loaded as "belly cargo" on passenger planes, where clearly the number of flights scheduled is solely a function of customer demand. To reflect true transportation costs, analysis must take into account the uncertainty in the probability of cargo being shipped with and without the food. Economies of scale must also be addressed in an analysis of production and transportation, looking at tonnes of produce per liter of fuel rather than per kilometer. For example, an apple from a truck that has transported 2,000 apples over $2,000 \mathrm{~km}$ will have "consumed" the same amount of fuel as an apple delivered in a bin of 50 apples to a farmers' market
$50 \mathrm{~km}$ from the orchard (McWilliams 2009). In some cases, car emissions to the distributor can be greater than transportation emissions during production or distribution (Larsen et al. 2008). A 1993 survey suggested that about $38 \%$ of London's allotment cultivators drive to their allotments, which no doubt significantly contributes to the carbon footprint (Saunders 1993). It has been well documented that dispersed/low-density cities are markedly more energyhungry and emission-intensive than high-density cities (Ewing and Rong 2008; Glaeser 2009), and to this end, it has been argued that urban agriculture could significantly increase the direct carbon footprint of a city by spreading it out even further (Glaeser 2011).

Life cycle analysis is a commonly used methodology for integrating energy flow into and out of a system (Rebitzer et al. 2004). However, LCAs of food imports and exports in the literature are limited in the number of countries and food types that have been analyzed (Edwards-Jones et al. 2008). Studies examining apple exports from New Zealand to the UK found contradictory results; a UK study found that local production was more energy-efficient (Jones 2002), while New Zealand studies suggested the opposite (Saunders et al. 2006; Saunders and Barber 2008). Clearly, there is a need for a consistent approach to defining system boundaries and a systematic methodology for comparing different systems. Assumptions such as time of year, production scale, the specific food type, and land use change will heavily influence the final carbon footprint calculation (Edwards-Jones et al. 2008; Plassmann et al. 2010). As it stands, more LCAs are needed on the whole range of agricultural goods across different cities before reliable conclusions can be drawn on carbon emissions between local and imported food.

\section{Australia}

\subsection{Wartime and post-wartime urban agriculture}

The history of urban agriculture in Australia follows similar trends to those in the USA and Britain, as documented by Gaynor (2006), from which the following description is largely drawn. During the 1930s, in the midst of deep economic recession, backyard "home gardens" and smallscale poultry farms were common, with $70 \%$ of people growing some of their own food. Informal campaigns to encourage wartime home food production started around 1941, but it was not until 1943 that the more serious and official Grow Your Own campaign was launched by the Commonwealth Department of Commerce and Agriculture. The media promoted the idea of manly independence, selfsufficiency, and patriotism associated with gardening to help feed the Allies, resulting in an additional 18,378 and 3,529 ha of vegetable production in Victoria and Western 
Australia from 1938 to 1944, respectively. An unpublished survey conducted by The University of Melbourne found that $48 \%$ of the sampled households in Melbourne were producing food of some kind in 1941, though such production was most common amongst the middle class or skilled working class rather than the poor and marginalized (Gaynor 2006). For the poor, even though food accounted for $40 \%$ of the total household expenditure, home food production was neither an effective nor accessible option.

Unlike in the USA, the sidelining of home food production in Australia after World War II was not as drastic, with more than $50 \%$ of vegetables grown in Victoria in the mid-1970s still being produced within $100 \mathrm{~km}$ of Melbourne (Gaynor 2006). On the other hand, lifestyle changes in the post-war era were significant as mainstream society embraced the novelty and convenience of supermarket shopping and frozen goods and improved technology allowed foods to be eaten out of season (Humphery 1998). At the same time, commercial agricultural production in metropolitan areas began shrinking in the 1950s. In Perth, Western Australia, the number of dairies fell from 101 in 1945 to 22 in 1957, and the extent of market gardens declined from 1,012 acres in 1945 to under 809 acres between 1950 and 1960 (Cooper 1979).

\subsection{Forms of contemporary urban agriculture}

The environmental movement that swept the USA during the 1970s brought back enthusiasm for urban agriculture in Australia as well (Gaynor 2006), although the resurgence took on different forms. An instrumental step in the movement was the introduction of permaculture by Bill Mollison and David Holmgren. Their book, Permaculture 1: A Perennial Agricultural System for Human Settlements, was published in 1978 and described an alternative agricultural system where plants, animals, and humans were integrated into the ecosystem and supported each other's functionality (Mollison and Holmgren 1978). Permaculture strategies include increasing biodiversity, mimicking ecosystem structures, building "guilds" of organisms that mutually support each other, and adapting to stages of plant succession (Jacke and Toensmeier 2005). These permaculture design principles became the foundation of a social and environmental philosophy about sustainable human habitats. Since the mid-1980s, permaculture techniques have been taught around the world, including Central and South America, Asia, and Africa, for use in backyards, community gardens, and larger-scale farms (Permaculture Global 2012). Some of the design principles of permaculture are based on tested scientific theories, such as "use and value diversity," "obtain a yield," and "catch and store energy," for example, which have been studied and implemented rigorously in conventional agricultural systems (e.g., Brussaard et al. 2010; Scherr and McNeely 2008; Walter 2003). However, in contrast to the intimidating plethora of peer-reviewed studies on the functioning of conventional agricultural systems (in terms of inputs, yield, and environmental impact), there is, to date, not a single peer-reviewed paper on the performance of a permacultural system. Such analyses are urgently required to place the costs and benefits of permaculture into context.

The first Australian community garden was established in Melbourne in 1977 prior to the permaculture movement (Hering 1995), but many community gardens around Australia today are linked with permaculture projects (Permaculture Global 2012). There are now at least 220 community gardens around the country, a number of them supported by local governments (Kingsley and Townsend 2006; Community Garden WA 2010; Community Garden Network 2012). Curiously, CSA programs are not popular in Australia, despite their success in the USA, with only two in the state of Victoria (Carey et al. 2010). Food education programs in schools, however, are popular. The Kitchen Garden Foundation, a primary school program where children learn to garden and cook the harvested fruits and vegetables, was started in 2001 and has now expanded to over 260 schools around Australia (Kitchen Garden Foundation 2012). Similar projects exist in the USA and UK, most famously Alice Waters' Edible Schoolyard Program and Jamie Oliver's School Dinners and Food Revolution documentary television shows.

In addition to these forms of urban agriculture, commercial peri-urban agriculture plays an important role in Australian food production. These regions account for $<3 \%$ of the land used for agriculture across the five mainland states, yet generate about $25 \%$ of Australia's total gross value of agricultural production, a conservative estimate due to the non-retail agricultural production not accounted for (Houston 2005). Melbourne, Sydney, and Adelaide in particular generate significant proportions of their respective state's fresh vegetables - up to $98 \%$ of cauliflowers in Adelaide, $99 \%$ of Asian vegetables in Sydney, and $97 \%$ of strawberries in Melbourne (Table 2). Intensive agriculture in the Sydney region represents up to $12 \%$ (AU $\$ 1$ billion) of the total agricultural production in the state of New South Wales (Gillespie and Mason 2003), and at least $11 \%$ of the state's agricultural workforce is employed within the city's boundary (Knowd et al. 2006). Farmers markets are a more recent addition, with the first one appearing in 1999. They have gained popularity; there are now at least 165 such markets across the country, primarily in metropolitan areas (Australian Farmers' Market Association 2012).

\subsection{Loss of peri-urban agricultural lands}

Loss of productive land in peri-urban areas due to land use changes has been significant in recent years (Millar and 
Table 2 Percentage of state fruit and vegetable production in major Australian cities by tonnage in 2009/2010 (ABS 2011) or 2008/2009 (ABS 2010)

\begin{tabular}{|c|c|c|c|c|c|c|c|c|}
\hline City & $\begin{array}{l}\text { Victoria } \\
\text { Melbourne }\end{array}$ & $\begin{array}{l}\text { New South } \\
\text { Wales } \\
\text { Sydney }\end{array}$ & $\begin{array}{l}\text { Queensland } \\
\text { Brisbane }\end{array}$ & $\begin{array}{l}\text { South } \\
\text { Australia } \\
\text { Adelaide }\end{array}$ & $\begin{array}{l}\text { Western } \\
\text { Australia } \\
\text { Perth }\end{array}$ & $\begin{array}{l}\text { Tasmania } \\
\text { Hobart }\end{array}$ & $\begin{array}{l}\text { Northern } \\
\text { Territory } \\
\text { Darwin }\end{array}$ & $\begin{array}{l}\text { Australian Capital } \\
\text { Territory } \\
\text { Canberra }\end{array}$ \\
\hline $\begin{array}{l}\text { All orchard fruit } \\
\text { (no. of trees) }\end{array}$ & $7(1,252,465)$ & $6(761,535)$ & $2(186,179)$ & $6(429,808)$ & $18(642,338)$ & $6(143,489)$ & $77(346,219)$ & NP \\
\hline Oranges & NP & $4(7,645)$ & NP & $0.03(39)$ & $11(690)$ & NP & NP & NP \\
\hline Mandarins & NP & $0.03(1)$ & NP & NP & $8(169)$ & NP & $100(2)$ & NP \\
\hline Apples & $22(24,845)$ & $3(1,162)$ & $0.4(126)$ & $11(1,966)$ & $17(6,111)$ & $\mathrm{NP}$ & NP & NP \\
\hline Pears & $5(3,969)$ & $2(9)$ & $\mathrm{NP}$ & $12(518)$ & $23(1,795)$ & $\mathrm{NP}$ & NP & NP \\
\hline Mangoes & NP & NP & $0.4(117)$ & $\mathrm{NP}$ & $0.3(4)$ & NP & $76(9,754)$ & NP \\
\hline Peaches & $0.4(231)$ & $34(2,125)$ & $\mathrm{NP}$ & $33(0.01)$ & $100(0.02)$ & $\mathrm{NP}$ & NP & NP \\
\hline Strawberries & $97(10,449)$ & $56(154)$ & $70(9,171)$ & $43(1,040)$ & $57(1,441)$ & $3(10)$ & NP & NP \\
\hline Bananas & NP & $\mathrm{NP}$ & $0.2(643)$ & $\mathrm{NP}$ & $\mathrm{NP}$ & $\mathrm{NP}$ & $91(5,438)$ & NP \\
\hline Grapes (wine and table) & $8(32,853)$ & $0.03(128)$ & $0.3(45)$ & NP & $7(6,188)$ & $23(1,756)$ & $\mathrm{NP}$ & $100(808)$ \\
\hline All vegetables (ha) & $33(10,316)$ & $24(3,888)$ & $1(273)$ & $13(2,058)$ & $19(1,721)$ & $2(365)$ & $56(436)$ & $100(20)$ \\
\hline Asian vegetables ${ }^{\mathrm{a}}$ & $89(4,394)$ & $99(8,749)$ & NP & $58(224)$ & $99(107)$ & $4(7)$ & $81(360)$ & NP \\
\hline Broccolia $^{\mathrm{a}}$ & $73(16,370)$ & $10(385)$ & NP & 63 (427) & $6(337)$ & NP & NP & NP \\
\hline Cabbage $^{\mathrm{a}}$ & $33(8,391)$ & $85(15,168)$ & $0.2(36)$ & $69(4,162)$ & $59(4,256)$ & NP & NP & NP \\
\hline Cauliflower $^{\mathrm{a}}$ & $97(18,976)$ & $38(4,285)$ & $0.1(20)$ & $98(7,781)$ & $13(861)$ & NP & NP & NP \\
\hline Lettuce $^{\mathrm{a}}$ & $73(37,777)$ & $56(11,428)$ & $1(510)$ & $23(2,758)$ & $24(2,777)$ & $98(1,442)$ & $100(38)$ & NP \\
\hline Carrots & $23(10,284)$ & $1(65)$ & NP & $55(17,167)$ & $12(9,377)$ & $\mathrm{NP}$ & $\mathrm{NP}$ & NP \\
\hline Potatoes & $18(49,284)$ & $5(6,673)$ & $0.04(34)$ & $9(31,144)$ & $6(5,020)$ & $0.002(6)$ & NP & NP \\
\hline Mushrooms & $87(12,841)$ & $81(11,898)$ & $26(712)$ & $94(3,347)$ & $\mathrm{NP}$ & $\mathrm{NP}$ & NP & NP \\
\hline $\begin{array}{l}\text { Tomatoes (fresh and } \\
\text { processing) }\end{array}$ & $0.3(996)$ & $35(19,402)$ & $0.4(386)$ & $66(9,336)$ & $75(9,814)$ & $65(1,060)$ & NP & NP \\
\hline Onions & $4(1,017)$ & NP & NP & $2(2,105)$ & $18(3,993)$ & NP & NP & NP \\
\hline
\end{tabular}

With the exceptions of all orchard fruit (trees) and all vegetable production (in hectares), all numbers in parentheses are tons of crop produced. Production in cities over $50 \%$ is marked in bold type

$N P$ no reported production

${ }^{a}$ Production in 2008/2009 (ABS 2010)

All other fruit and vegetable production in 2009/2010 (ABS 2011)

Roots 2012). Though there are no national data demonstrating that these losses have resulted from expanding urban sprawl, over the last 10 years, there has been a decline of total agricultural land across Australia from 456 million hectares in 2001 to 399 million hectares in 2010 (ABS 2011). There is a general acceptance or expectation that agricultural lands will be developed for other uses, particularly in the coastal peri-urban areas, despite the suitability of such land for agriculture (PMSEIC 2010). At the Royal Australian Planning Institute Conference in Western Sydney in 1993, in response to a question on agricultural planning in Sydney, a planning official replied: "There is no place for agriculture in the Sydney region, agriculture belongs over the [Great Dividing] Range and any agricultural land is land awaiting higher economic development" (Mason and Knowd 2010, p. 64).

Some state and local governments, such as those in Victoria and Sydney, have proposed plans and zoning boundaries to protect agricultural lands against urbanization, with mixed results (Mason and Knowd 2010; Millar and Roots 2012). Within metropolitan Melbourne, significant portions of horticultural and agricultural lands have been handed over to other uses over the last half of the century (Carey et al. 2010). Such changes have spurred significant media coverage of food security concerns, the "right to farm" in peri-urban areas, ongoing land use conflicts, and food policy (SBS 2010; Millar and Fyfe 2012a; The Age 2012). The realignment of Melbourne's urban growth boundary to include key areas in the western and eastern horticultural precincts has caused land values to increase several times over, and many farmers are choosing to sell their land to developers (Carey et al. 2010; Millar and Roots 2012). Given the significant level of agricultural production in Australian cities (Table 2), such land use changes could have devastating impacts on agricultural production as a whole. This familiar story of agriculture being pushed out by urbanization, market factors, and an aging farming population has played out many times around the world, from Greater London to North America to Melbourne (Lobao and Meyer 2001; 
Low Choy et al. 2008; DEFRA 2010; Francis et al. 2012).

\subsection{Food policy plans}

The loss of agricultural lands has fed into recent debates about Australian food security, compounded by predictions that Australia's population will reach 36 million by 2050 and that the world will need to increase food production by $70-100 \%$ to cope with climate change and energy security scenarios (FAO 2009; Commonwealth of Australia 2010; Millar and Roots 2012). Australia exports $60 \%$ of its total agricultural production, primarily cattle, wheat, and milk, while Australian farmers supply $93 \%$ of Australia's domestic food supply (PMSEIC 2010; ABARES 2011). Maintaining this level of agricultural production will require responses to a range of challenges such as climate change vulnerabilities, soil fertility decline, and water scarcity in certain social sectors.

The Australian government is in the process of developing a National Food Plan to "...ensure Australia has a sustainable, globally competitive, and resilient food supply, supporting access to nutritious and affordable food" (DAFF 2012). The use of existing urban and peri-urban lands for food production through encouragement of community gardens, backyard gardens, and integration of edible landscapes into planning was raised as a key issue in stakeholder meetings, but there are no actions currently planned to address this (DAFF 2012). Instead, the approach is to continue support of existing commercial agricultural sectors in urban centers outside the state or territory capitals, known as regional cities (Beer et al. 1994), since more than $90 \%$ of food production jobs are located there.

The economic importance of agriculture in regional areas is also recognized by the regional cities themselves. In places such as Greater Shepparton in regional Victoria, supporting the agricultural sector is crucial in the municipality's latest urban plans (GSCC and Coomes Consulting 2006). But no explicit connection to the consumption of local food or support of social initiatives related to food security was made in the Greater Shepparton urban plan, despite evidence of food insecurity issues in regional cities (GSCC and Coomes Consulting 2006). For example, in $2008,8.1 \%$ of people in the municipality of Greater Shepparton suffered from food insecurity and $53.9 \%$ of residents did not meet national guidelines for recommended daily fruit and vegetable consumption compared to 5.6 and $48.2 \%$, respectively, across the state of Victoria (GVPCP 2011). The urban agriculture movement is establishing a presence though: a recent newspaper article stated that people in the Goulburn Valley of Victoria are fed up with the supermarkets' lack of produce from the local region and that there has been an "extraordinary explosion" of farmers' markets in response (Millar and Fyfe 2012b).
Indeed, the establishment of the Greater Shepparton Food Security Alliance in late 2011 marked the start of discussions about urban agriculture and its role in food security in regional cities.

A commitment to local food production and consumption is seen more clearly in Melbourne, Victoria's capital city. The city council recently released the City of Melbourne Food Policy and is preparing an accompanying food policy action plan (City of Melbourne 2012). Already, the city council has made commitments to increase production, distribution, and consumption of locally (within $50 \mathrm{~km}$ of the municipality) and regionally grown food to $30 \%$ of the total consumption (City of Melbourne 2008). The Food Policy plan includes explicit ambitions to increase food production within the City of Melbourne, advocating for the preservation of peri-urban agricultural lands along Melbourne's fringe and supporting innovative forms of local agriculture (City of Melbourne 2012). But it is not clear how consumption is defined in the plan (limited to fruits and vegetables or inclusive of cereals and meats) nor how goals for increasing food production will be achieved and what their impact on other goals, such as biodiversity and open space preservation, will be. Also, the State's agriculture department, the Department of Primary Industries, is notably absent from the plan and its development.

\subsection{Water for agriculture in a dry city}

Water security is a continuing challenge worldwide, and Australia is not exempt, with recent droughts putting strain on both agricultural and urban water supplies (Radcliffe 2010). As water is a critical resource for urban agriculture, continuous and reliable access to water of a high quality is important. Around the world, water supplies for urban agriculture vary, with most sources in developing nations being either raw or diluted wastewater (Hamilton et al. 2007, 2013). The city of Melbourne provides a number of useful examples of centralized and decentralized wastewater irrigation options for urban agriculture. The two largest wastewater treatment plants in Melbourne underwent upgrades and now supply reclaimed water to neighboring market gardens on the peri-urban fringe. The Western Treatment Plant provides around $61 \mathrm{ML}$ per day of high-quality reclaimed water to around 170 customers, while the Eastern Treatment Plant supplies $30 \mathrm{ML}$ per day of high-quality water to approximately 80 customers (Barker et al. 2011). At the household scale, many residents responded to water restrictions by establishing informal (bucketing graywater onto gardens) or formal (fixed reuse systems) graywater reuse schemes for home vegetable gardens (Barker et al. 2011, 2013). A recent study found that $67.6 \%(1,095 / 1,621$, from 2007 to 2011) of surveyed respondents across Melbourne were graywater users (Sinclair et al. 2011). While there are no 
data to determine how much of this water was used in urban food production, it is reasonable to assume that a significant proportion was devoted to irrigating backyard vegetable plots and fruit trees. Untreated graywater reuse is not regulated by legislation, but EPA guidelines exist and recommend that graywater not be used on vegetables and crops that are eaten raw to reduce any risks of contamination from graywater irrigation (EPA Victoria 2008).

The most obvious source of water at the household and community garden level is the mains water supply, although rainwater harvesting also has a long tradition of domestic use in Australia. Residential rainwater harvesting has recently been promoted through subsidies from governments and water authorities; simultaneously, restrictions limiting outdoor use of mains water have encouraged the installation of rainwater tanks for garden use (Devi et al. 2005; Barker et al. 2011). Another potential source of water for urban agriculture that remains to be explored is storm water. Modeling for Melbourne predicts an annual volume of 463 GL from urban runoff, of which only $10 \mathrm{GL}$ (storm water and rainwater) are currently harvested and used so far, mostly for third-pipe or dual-pipe schemes involving reticulation systems separate from drinking water (Living Victoria Ministerial Advisory Council 2012).

\section{Japan}

\subsection{Mixed rural-urban landscapes}

Japan provides an interesting context for investigating the role of urban agriculture in urban planning and food security. As a country with declining population growth rates and a food self-sufficiency ratio (percentage of people's daily calorific intake derived from domestically produced food) at an astonishingly low of $40 \%$ (Kitahara 2003), Japan is heavily reliant on the global agricultural market. This has placed Japan in a somewhat vulnerable situation, and these concerns have spurred both government and citizens to action.

In contrast to many Western developed countries, the mixture of rural and urban land uses, including agricultural cultivation, has long been in the history of Japanese cities, as documented by Yokohari et al. (2000), from which most of the following information is drawn. As far back as the eighth century, several city blocks in Kyoto have remained as agricultural land-even through the feudal eras. Similarly, the city of Edo (now Tokyo) had planned agricultural farmland amid residential areas even during the population expansions of the eighteenth and nineteenth centuries. Figure 5 shows an extract of a map of Edo from the early nineteenth century, illustrating a neighborhood $4 \mathrm{~km}$ east of Edo Castle, where rice paddies (in black) are scattered among residences. Since the area was mostly under sea before land reclamation projects occurred, these fields are not remnants of farmland that previously dominated the landscape. Rather, it is hypothesized that these paddy fields were intentionally planned as both a source of rice for food security and as reservoirs that prevented flooding during storm surges. Historical records suggest that $40 \%$ of Edo land was used for agriculture in the 1800 s (Yokohari et al. 2010), and much of this was defined as gardens. These gardens were not merely for recreation-they were sites of legitimate agricultural production. Similar to the Lea Valley cucumbers of London, the present-day names of a variety of vegetables originate from names of Edo districts where they were grown, such as "Nerima-daikon" (radish), "Komatsu-na" (rape), and "Yanaka-shouga" (ginger; Yokohari et al. 2010).

\subsection{Decline of food self-sufficiency}

During the twentieth century, population growth and subsequent urban development pushed agriculture out of the cities. Prior to 1968, Japanese urban planning focused primarily on key industrial infrastructure to promote economic growth, and little effort was given to plan or regulate residential development (Sorensen 2000). As a result of rapid economic growth, from the late 1950s onward, urban areas expanded into the agricultural countryside, resulting in the widespread establishment of peri-urban fringe areas across Japan (Ichikawa et al. 2006; Kurita et al. 2009; Yokohari et al. 2010). The 1968 City Planning Act attempted to contain urbanization through distinct land zones which urbanization

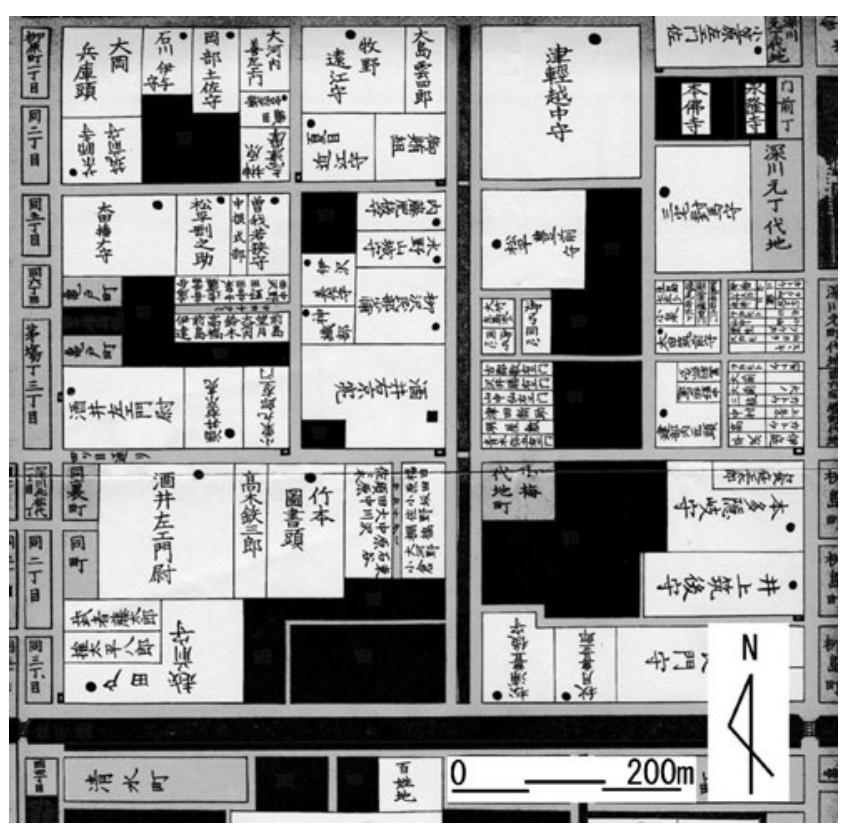

Fig. 5 Typical residential neighborhood in Edo (now Tokyo) during the nineteenth century. Black patches represent rice paddies, whereas white spaces represent mixed residential and commercial uses (republished with permission from Yokohari et al. 2000) 
could and could not occur in, but mixed land use still occurred within sectioned-off lands (Nakai 1988). This rampant urbanization has presented a significant challenge to domestic agricultural production near urban areas. The area devoted to rice production in Tokyo was at its peak in 1897 (17,726 ha) but, with the exception of two periods of growth, has steadily decreased over the last 100 years to only 222 ha in 2002 (Kamoshita 2007).

Urbanization has not been the only driving force behind the decline of agriculture. As with other developed countries, Japan's post-World War II food policies promoted modernization, industrialization, and globalization and encouraged the rural farming sector to join the growing industrial sector (Ichikawa et al. 2006; Kimura and Nishiyama 2008). Japan's importation of agricultural goods increased steadily in the post-war years, and domestic agricultural production decreased. In 2000, Japan's farmland accounted for only $14 \%$ of the total land area, and many rural farming communities had transitioned to mixed societies in which agriculture was no longer dominant (Kitahara 2003). This, coupled with an aging farming population and increasing numbers of abandoned agricultural lands, led to a sharp decline in the food self-sufficiency ratio from $73 \%$ in 1965 to $40 \%$ in 2000 (Kitahara 2003). Approximately $60 \%$ of staple agricultural products consumed in Japan are now imported, with import rates as high as $74 \%$ for all cereals and $100 \%$ for maize (FAO 2012; Japan Ministry of Health Labour and Welfare 2012).

\subsection{Food policy and local food movements}

Concerns about food security were elevated by a series of food-related scandals, such as corporate falsification of labels and food poisoning, and both government and the public began to campaign for food reform (Imamura et al. 2007; Kimura 2011). Since the mid-1990s, there has been a movement to re-localize food production in the city through the chisan-chisho ("locally produced, locally consumed") initiative (Kimura and Nishiyama 2008). Started by nongovernmental organizations, the movement was later taken up by local governments and Japan Agriculture Cooperative farmer collectives. Actions range from raising awareness about the benefits of local food, encouraging food education and gardens in schools, promoting local eating through marketing campaigns, "eat-local" days, and direct farmer sales stands known as chokubaijo (Kimura and Nishiyama 2008). Chisan-chisho gained further legitimacy when the national Japanese government included it in its 2002 Revitalization Plan for Food and Agriculture and in the 2005 New Basic Plan as a way to increase domestic consumption (Kimura and Nishiyama 2008). While chisan-chisho focused primarily on changing social perceptions around local food as a safer and better option, rather than encouraging self-production of food, arguably such a social movement is necessary for the success of an alternative food system.

Shokuiku ("food education") was also institutionalized with the national Food Education Basic Law in 2005 (Mah 2010). It emphasized a traditional Japanese-style diet with the family and increased consumption of local food through methods such as school nutrition programs, "shokuiku day," and major campaigning (Kimura 2011; Miyoshi et al. 2012). The goal was to address a wide range of food policy and health issues such as the increased incidence of obesity and cardiovascular disease among Japanese people, overdependency on food imports, and the recent food scandals (MAFF 2006). Nationalism played a huge role in this policy-citizen support of local food was a way to bolster the national image and market Japanese food and lifestyle as a global commodity (Kimura 2011). Rice was presented as the very foundation of the ideal meal, using its cultural significance to strengthen nationalism (Mah 2010; Kimura 2011). The focus on individual responsibilities to eat healthier diets, and especially the responsibility of women to prepare home-cooked meals, has overshadowed other issues (Kimura 2011). Better regulation of food corporations and distribution systems to avoid food incidents and alternative agricultural systems are not mentioned in the food policy plan.

In addition to raising social awareness about local food, a special agricultural leasing program, called ona seido ("ownership system") was started in 1992 to allow non-farmer urbanities to rent agricultural land and produce food (Kieninger et al. 2011). The program has grown in popularity, and in 2008, there were 187 ownership programs around Japan (Kieninger et al. 2011). The urbanite-turned-agriculturalists are primarily people from older generations who are motivated by a desire for a connection with nature, self-sufficiency in food, landscape conservation, better quality of food, and other factors (Yokohari et al. 2010; Kieninger et al. 2011). Isolated or abandoned farmland patches in the peri-urban fringes were ideal sites, and some tenants maintained large plots in peri-urban areas, typically over $100 \mathrm{~m}^{2}$ each, and actually became semiprofessional in their agricultural activities (Yokohari et al. 2010; Kieninger et al. 2011). The ona seido was distinct from the shimin noen ("citizen-garden"), which were small unused agricultural plots that became recreational spaces during the 1990s (Yokohari et al. 2010). The shimin noen were based on the German Kleingarten leisure garden model and were heavily serviced by the landowners (Wiltshire and Azuma 2000; Yokohari et al. 2010). The 1989 Agricultural Land (Allotments) Rental Law made it possible for farmers to rent out land for garden use, both in urban and rural municipalities, and by 1998, around 200,000 people were shimin noen holders (Wiltshire and Azuma 2000). But the impact of these leisure gardens was much less substantial than other similar systems because the average garden area was only $50 \mathrm{~m}^{2}$ (Yokohari et al. 2010). 


\subsection{Environmental impacts and public health risks}

Similar to many other industrialized countries, Japan experienced a number of environmental crises in the wake of rapid urbanization and economic growth. The laissez-faire urban planning approach enabled the establishment of large areas of intermixed agricultural, residential, industrial, and commercial land (Sorensen 2000), with conflicts arising between the various land uses. The proximity of agricultural lands to residential areas has increased human exposure to agrochemicals. In an agricultural community in the suburbs of Tokyo, it was found that aerosols of organophosphate pesticide-infiltrated houses and childcare facilities located near farms and, depending on the nature of the pesticide, exposure from indoor air constituted a significant portion of the daily pesticide inhalation (Kawahara et al. 2005). Surface runoff from agricultural pesticides has also contributed to the degradation of water quality and increased toxicity to aquatic organisms (Okamura et al. 2002; Iwafune et al. 2011). In addition, intensive fertilizer use has significantly increased nitrate concentrations in groundwater near tea plantations, orchards, vegetable fields, and livestock farms, including those areas in close proximity to urban centers (Kumazawa 2002; Gallardo et al. 2005).

Agriculture is not the only source of pollution because food grown in urban areas can be contaminated by industrial pollution. Cadmium contamination is especially prevalent in Japan due to its long history of metal mining and factory work dating back to the Meiji Era, from 1868 to 1912 (Arao et al. 2010). The itai-itai disease, a type of chronic cadmium poisoning, emerged in Japan around 1912, but the cause of the disease remained unknown until 1961, when a doctor detected large amounts of cadmium in the cremation ashes of a patient who died of itai-itai (Imamura et al. 2007). Eventually, the link was made to locally grown rice irrigated with cadmium-contaminated river water from the Kamioka Copper Mine (Imamura et al. 2007; Arao et al. 2010). Dietary consumption of rice was and still is almost exclusively the source of cadmium intake, and given the government's promotion of rice as the meal staple, clearly, the contamination issue needs to be addressed as a matter of urgency (Tsukahara et al. 2003; Ikeda et al. 2004, 2006). Regulation of cadmium contamination of food and agricultural soils began in the 1970s, but the levels of cadmium in Japanese people were still found to be highest among other East and Southeast Asian countries during the 1990s (Watanabe et al. 1996; Ikeda et al. 2000; Arao et al. 2010). It may take several more decades for countermeasures to significantly reduce cadmium contamination in agricultural soil.

\section{Conclusions}

Urban agriculture has taken many different forms in the developed world over the course of the last century. Though there are negative impacts from such agricultural activities, urban food production continues to make a significant contribution to the social and economic well-being of many. Through this global review, we have identified five highpriority issues requiring further investigation.

1. A continual threat to urban agriculture is the loss of agricultural land in urban and peri-urban areas. Urban sprawl and the widening disparity between the capitalized value of farmland and the opportunity price for urban use, as described in the Australian context, are occurring around the world, resulting in less and less agricultural land in and near cities. The impacts of this on food production require more understanding. Methods to address urban growth should not be applied uniformly. Use of growth boundaries and controlled greenbelts may be appropriate for some areas, for example in European cities, but not others, such as in Asian mega-cities (Yokohari et al. 2000).

2. Infrastructure and support for urban farmers at individual, community, and commercial levels need to be included in food policy plans for urban agriculture to be viable. In some cases, such as in the USA, evidence of such support is visible. Depending on the scale of urban agriculture, different types of institutional support are needed at the local, city, state, and country levels. Even if food policy plans are not developed, management of urban agriculture needs to be included in major city planning documents. Urban growth boundaries in particular will have a major impact on land availability and, thus, food production. Regulation of vacant lot use should include mention of agricultural activities, bearing in mind potential negative impacts such as soil contamination, fertilizer use, and groundwater pollution. Without appropriate mechanisms of governance, urban agricultural activities may develop inefficient and uncoordinated ways.

3. The role of urban agriculture in increasing the selfsufficiency of cities requires more understanding. While the economic benefits of globalization and free trade are doubtless, cases such as Japan highlight the social impacts of heavy reliance on imported goods. There is little literature on whether self-sufficiency in food production is necessary or feasible, and given the expected increase in population and food demand in the coming decades, this issue should be more closely scrutinized. Vertical farming may have a role to play, however small, in city self-sufficiency, but much more quantitative analysis is needed to back the theoretical ideas put forth by Despommier (2010).

4. The risks posed by industrial or traffic pollution of locally grown food need to be addressed. With land use change and conversion of industrial land to 
residential or other purposes, brownfield regulations should be very clear to ensure that food production avoids areas of soil contamination and heavy metal exposure. Information should also be distributed at the household level regarding soil testing and the safety of backyard gardens. On the other end, more incentives for developers to remediate brownfields are necessary to prevent environmental injustice to communities living in areas with high proportion of contaminated lands. Although the impact of air pollution on urban agriculture is not as much of a serious concern in the developed world as in the developing world (Hamilton et al. 2013), air pollution has been shown to contribute to heavy metal contamination of vegetables grown in hightraffic areas of developed countries (Hough et al. 2004; Bell et al. 2011; Saumel et al. 2012). The impact of agricultural activities on residential areas or vulnerable ecosystems should also be thoroughly investigated as significant risks exist, as demonstrated by the contamination of water supplies with agrochemical pollutants in Japan.

5. Food miles and the broader debate about the carbon footprint of urban agriculture require more detailed investigation. Methods for LCAs are not uniform across studies, and currently, the costs and benefits are typically considered without regard to parameter uncertainty. Optimization of carbon emissions from agriculture is a highly complex calculation and depends heavily on the context of the particular city setting as well as the food product in question. Thus, while the concept of "food miles" is too simplistic an indicator for carbon emissions, it cannot be said whether local food as a whole is any worse or better than imported goods. Furthermore, given the economic and political implications of local food as protectionism, it is imperative that any emission analysis of urban agriculture be objective and rigorous.

The justification for urban agriculture in the developed world is often presented very differently from that in the developing world (Hamilton et al. 2013). In the developing world, urban agriculture is typically a matter of subsistence survival; in the developed world, it is hailed as part capitalism and part ideology. Although urban agriculture in the developed world has long been dismissed as a by-product of the environmental movement and a feel-good activity for the bourgeoisie, it is undeniable that the economic contributions of food produced from urban (especially peri-urban) agriculture can be quite significant, as seen in Australia. It would be an inaccurate generalization to say that participation is limited to the higher socioeconomic classes in developed countries. In places such as the USA and Canada, urban agriculture is a tool for marginalized communities to increase food security as well as social and economic well- being. Given the importance of both positive and negative effects, it is time that urban agriculture be taken seriously in the developed world.

The question presented in this review then is whether there will indeed be strawberry fields forever in cities. The current trends of urban agriculture across the developed world indicate that the practice is growing and evolving as crises emerge and fade. Yet, with growing urban populations worldwide, how much of these strawberry fields should be in cities? Already, there is inter-sector competition between agricultural, industrial, and residential needs for energy, water, and land in urban areas, and continuing to expand all sectors in a limited space will result in greater management and resource allocation problems.

As discussed in the accompanying publication of urban agriculture in the developing world (Hamilton et al. 2013), this, ultimately, is a complex optimization problem of how much land and resources should be given to agricultural and other activities in cities. The benefits and costs outlined qualitatively in this review should be quantified in the context of a city's other functions, such as industrial manufacturing, residential housing, and trade. To what extent would urban agriculture's smaller-scale farms and fragmented nature be less efficient with respect to water, fertilizer applications, harvesting, and other operations than conventional agriculture, and what are the implications with respect to greater land and energy requirements? Does the need to build houses and industrial operations outweigh the need to produce food near or within cities? Would the combined carbon emissions of consumers driving to their local community garden be equal to the emissions of importing food from overseas? How much are people willing to pay for local fresh produce in cases of unsuitable climate and inefficient resource availability? Even if the uncertainties of all these parameters can be estimated for such a model, there remain questions that cannot be modeled so readily. For example, are there moral dilemmas associated with denying developing countries the option of exporting food to wealthier nations in lieu of locally grown food in developed countries (Müller 2007)? And what are the moral implications of not addressing the issue of food deserts in developed countries?

There is no single solution to the global food crisis, and urban agriculture will certainly not be a silver bullet. Overemphasizing the benefits of urban agriculture without regard to its downsides is dangerous and risks marginalizing this movement back to its perceived hippie roots, particularly in developed countries. Rather, a balance of urban and conventional agricultural production should be sought - an optimal level that will differ from country to country and city to city. To reach this balance, however, urban agriculture needs to be taken seriously and its potential contributions to food production assessed rigorously. This will take 
the combined efforts of citizens, scientists (biophysical, social, and political), economists, engineers, mathematicians, and planners.

Acknowledgments Jeanette Longfield, Ben Reynolds, and Suzanne Natelson provided useful feedback on the London section of the paper, for which we are most grateful. We thank Dr. Patrick Laplagne for comments on a draft of the manuscript.

Open Access This article is distributed under the terms of the Creative Commons Attribution License which permits any use, distribution, and reproduction in any medium, provided the original author(s) and the source are credited.

\section{References}

ABARES (2011) Agricultural commodities statistics, 2011. Australian Bureau of Agricultural and Resource Economics and Sciences; Department of Agriculture, Fisheries, and Forestry, Canberra, Australia

ABS (2010) 7121.0 - Agricultural commodities, Australia, 2008-09. Australian Bureau of Statistics, Canberra, Australia

ABS (2011) 7121.0 - Agricultural commodities, Australia, 2009-10. Australian Bureau of Statistics, Canberra, Australia

Alberini A, Longo A, Tonin S, Trombetta F, Turvani M (2005) The role of liability, regulation and economic incentives in brownfield remediation and redevelopment: evidence from surveys of developers. Reg Sci Urban Econ 35:327-351. doi:10.1016/ j.regsciurbeco.2004.05.004

Allotment.org.uk (2012) Allotment history - a brief history of allotments in the UK. http://www.allotment.org.uk/grow-your-own/ allotments/history. Accessed 30 June 2012

American Farmland Trust (2012) Farm bill 2012: a time for transformation. American Farmland Trust. http://www.farmbillfacts.org/. Accessed 24 September 2012

Anon (2011) Bid to protect Lea Valley cucumbers. New Market Journal, 8 October 2011, United Kingdom

Arao T, Ishikawa S, Murakami M, Abe K, Maejima Y, Makino T (2010) Heavy metal contamination of agricultural soil and countermeasures in Japan. Paddy Water Environ 8:247-257. doi:10.1007/s10333-010-0205-7

Assembly L (2006) A lot to lose: London's disappearing allotments. Environment Committee, London Assembly: Greater City of London, London, UK

Australian Farmers' Market Association (2012) Australian Farmers' Market Association. http://www.farmersmarkets.org.au/. Accessed 07 June 2012

Baker AJM (1981) Accumulators and excluders-strategies in the response of plants to heavy metals. J Plant Nutr 3:643-654

Barker SF, O'Toole J, Sinclair M, Malawaraarachchi M, Leder K, Hamilton AJ (2013) Human health risks from greywater irrigation: consumption of home-grown vegetables in Melbourne, Australia. Water Res 47:421-432

Barker S, Faggian R, Hamilton A (2011) A history of wastewater irrigation in Melbourne, Australia. J Wat Sustain 1:31-50

Bassett T (1981) Reaping on the margins: a century of community gardening in America. Landscape 25(2):1-8

Beaulac J, Kristjansson E, Cummins S (2009) A systematic review of food deserts, 1966-2007. Prev Chron Dis 6:1-9

Beer A, Bolam A, Maude A (1994) Beyond the capitals: urban growth in regional Australia. Australian Government Publishing Service, Canberra
Bell JNB, Power SA, Jarraud N, Agrawal M, Davies C (2011) The effects of air pollution on urban ecosystems and agriculture. Int J Sustain Dev World 18:226-235. doi:10.1080/ 13504509.2011 .570803

Blanke MM, Burdick B (2005) Food (miles) for thought—energy balance for locally-grown versus imported apple fruit. Environ Sci Pollut Res 12:125-127. doi:10.1065/espr2005.05.252

Boulding JR, Ginn JS (2004) Practical handbook of soil, vadose zone, and ground-water contamination: assessment, prevention, and remediation. Lewis, Boca Raton

BrightFarms (2012) Sunset park, Brooklyn greenhouse. http:// brightfarms.com/projects/sunset-park-brooklyn. Accessed 6 June 2012

Brown DG, Johnson KM, Loveland TR, Theobald DM (2005) Rural land-use trends in the conterminous United States, 1950-2000. Ecol Appl 15:1851-1863. doi:10.1890/03-5220

Brown K, Jameton A (2000) Public health implications of urban agriculture. J Pub Health Pol 21:20-39

Brown KH, Carter A (2003) Urban agriculture and community food security in the United States: farming from the city center to the urban fringe. Community Food Security Coalition, North American Urban Agriculture Committee

Brussaard L, Caron P, Campbell B, Lipper L, Manika S, Rabbinge R, Babin D, Pulleman M (2010) Reconciling biodiversity conservation and food security: scientific challenges for a new agriculture. Curr Opin Environ Sust 2:34-42

Bryld E (2003) Potentials, problems, and policy implications for urban agriculture in developing countries. Agric Hum Val 20:79-86. doi:10.1023/a:1022464607153

Budge T (2009) The decline and rise of urban agriculture: can urban agriculture deliver on multiple urban planning and policy fronts? State of Australian Cities Conference, Perth, Western Australia

Butler C, Butler E, Orians CM (2012) Native plant enthusiasm reaches new heights: perceptions, evidence, and the future of green roofs. Urb Fores Urb Green 11:1-10. doi:10.1016/j.ufug.2011.11.002

Campbell M, Campbell I (2011) Allotment waiting lists in England 2011. Transition Town West Kirby, National Society of Allotment and Leisure Gardeners, United Kingdom

Capital Growth (2012) Capital Growth. http://www.capitalgrowth.org/. Accessed 30 June 2012

Carey R, Krumholz F, Duignan K, McConell K, Browne JL, Burns C, Lawrence M (2010) Integrating agriculture and food policy to achieve sustainable peri-urban fruit and vegetable production in Victoria, Australia. J Agric F Sys Commun Dev 1:181-195

Chen TB, Wong JWC, Zhou HY, Wong MH (1997) Assessment of trace metal distribution and contamination in surface soils of Hong Kong. Environ Pollut 96:61-68. doi:10.1016/s0269-7491(97)00003-1

City of Melbourne (2008) Future Melbourne plan. City of Melbourne, Melbourne, Australia

City of Melbourne (2012) City of Melbourne food policy. City of Melbourne, Melbourne, Australia

City of Toronto (2012) Green roof bylaw. http://www.toronto.ca/ greenroofs/overview.htm. Accessed 6 June 2012

Commonwealth of Australia (2010) Australia to 2050: future challenges. The 2010 intergenerational report. Commonwealth of Australia, Canberra, Australia

Community Garden Network (2012) Australian city farms and community gardens network. http://communitygarden.org.au/. Accessed 8 June 2012

Community Garden WA (2010) Directory of Western Australia community gardens. http://communitygardenswa.org.au/media/articles/Directoyof-WA-Community-Gardens/Directory-of-WA-CommunityGardens.pdf. Accessed 9 June 2012

Cooper WS (1979) Drainage and irrigation. In: Gentilli J (ed) Western landscapes. University of Western Australia Press, Nedlands, pp 245-252 
Crouch D, Ward C (2003) The allotment: its landscape and culture. Five Leaves Publications, Nottingham, UK

D'Angelo H, Suratkar S, Song H-J, Stauffer E, Gittelsohn J (2011) Access to food source and food source use are associated with healthy and unhealthy food-purchasing behaviours among low-income African-American adults in Baltimore city. Publ Health Nutr 14:1632-1639. doi:10.1017/ s1368980011000498

DAFF (2012) National food plan green paper. Department of Agriculture, Fisheries and Forestry, Canberra, Australia

Dawson D, Worrell A (1992) The amount of each kind of ground cover in Greater London. London Ecology Unit, London, UK

De Bon H, Parrot L, Moustier P (2010) Sustainable urban agriculture in developing countries. A review. Agron Sustain Dev 30:21-32

De Sousa CA (2003) Turning brownfields into green space in the city of Toronto. Landsc Urban Plann 62:181-198. doi:10.1016/s01692046(02)00149-4

De Vries K, Heyboer K (2011) Stranded in 'food deserts', hundreds of NJ residents lack access to healthy fresh food. The Star Ledger, 8 August 2011, New Jersey

DEFRA (2008) Comparative life-cycle assessment of food commodities procured for UK consumption through a diversity of supply chains. Department for Environment, Food and Rural Affairs, United Kingdom

DEFRA (2010) June survey of agriculture and horticulture. County level crop areas/livestock numbers/labour force. Department for Environment and Rural Affairs, United Kingdom

Deportes I, Benoitguyod JL, Zmirou D (1995) Hazard to man and the environment posed by the use of urban waste compost - a review. Sci Total Environ 172:197-222. doi:10.1016/0048-9697(95) 04808-1

Despommier D (2010) The vertical farm: feeding the world in the 21st century. St. Martin's Press, New York

Devi B, Maheshwari B, Simmons B (2005) Rainwater harvesting for residential irrigation: how sustainable is it in urban context. XII International Rainwater Catchment Systems Conference, Vigyan Bhawan, New Delhi, India

Economist (2011) Food deserts: if you build it, they may not come. The Economist, 7 July 2011, Seattle

Edwards-Jones G, Canals LMI, Hounsome N, Truninger M, Koerber G, Hounsome B, Cross P, York EH, Hospido A, Plassmann K, Harris IM, Edwards RT, Day GAS, Tomos AD, Cowell SJ, Jones DL (2008) Testing the assertion that 'local food is best': the challenges of an evidence-based approach. Tren F Sci Technol 19:265-274. doi:10.1016/j.tifs.2008.01.008

Engelhard B (2010) Rooftop to tabletop: repurposing urban roofs for food production. Master of Landscape Architecture, Department of Landscape Architecture, University of Washington

EPA Victoria (2008) Greywater use around the home. Publication No. 884.1. Environmental Protection Agency Victoria, Southback, Victoria

Eriksen-Hamel N, Danso G (2010) Agronomic considerations for urban agriculture in southern cities. Int J Agron Sust 8:86-93. doi:10.3763/ijas.2009.0452

Ewing R, Rong F (2008) The impact of urban form on US residential energy use. Housing Pol Debate 19:1-30

FAO (2007) Profitability and sustainability of urban and peri-urban agriculture. Agricultural management, marketing and finance occasional paper. FAO, Rome

FAO (2009) Feeding the world in 2050. FAO, Rome

FAO (2012) Food outlook: global market analysis. May 2012. FAO, Rome

Fischer G, Shah M, Tubiello FN, van Velhuizen H (2005) Socio-economic and climate change impacts on agriculture: an integrated assessment, 1990-2080. Philos Trans R Soc Lond Ser B 360(1463):2067-2083. doi:10.1098/rstb.2005.1744
Follett JR (2009) Choosing a food future: differentiating among alternative food options. J Agr Environ Ethic 22:31-51

Food and Hunger Action Committee (2003) Tending the garden. City of Toronto, Toronto, Canada

Francis CA, Hansen TE, Fox AA, Hesje PJ, Nelson HE, Lawseth AE, English A (2012) Farmland conversion to non-agricultural uses in the US and Canada: current impacts and concerns for the future. Int J Agron Sust 10:8-24. doi:10.1080/14735903.2012.649588

Franco M, Roux AVD, Glass TA, Caballero B, Brancati FL (2008) Neighborhood characteristics and availability of healthy foods in Baltimore. Am J Prev Med 35:561-567. doi:10.1016/ j.amepre.2008.07.003

Gallardo AH, Reyes-Borja W, Tase N (2005) Flow and patterns of nitrate pollution in groundwater: a case study of an agricultural area in Tsukuba City, Japan. Environ Geol 48:908-919. doi:10.1007/s00254-005-0029-8

Garnett T (1999a) City harvest: the feasibility of growing more food in London. Sustain, United Kingdom

Garnett T (1999b) Urban agriculture in London: rethinking our food economy. International Workshop Growing Cities Growing Food: Urban Agriculture on the Policy Agenda, 11-15 October 1999, Havanna, Cuba

Gaynor A (2006) Harvest of the suburbs: an environmental history of growing food in Australian cities. UWA Press, Crawley

Germer J, Sauerborn J, Asch F, de Boer J, Schreiber J, Weber G, Muller J (2011) Skyfarming an ecological innovation to enhance global food security. J Cons Prot F Saf 6:237-251

Getter KL, Rowe DB (2006) The role of extensive green roofs in sustainable development. Hortscience 41:1276-1285

Gillespie PD, Mason D (2003) The value of agriculture in the Sydney region: February 2003. New South Wales Agriculture, Environmental Planning \& Management Sub-Program, Sydney

Glaeser EL (2009) Green cities, brown suburbs. City J 9:50-55

Glaeser EL (2011) The locavore's dilemma: urban farms do more harm than good to the environment. Boston Globe, 16 June 2011, Boston, MA

Glaeser EL, Kahn ME (2010) The greenness of cities: carbon dioxide emissions and urban development. J Urban Econ 67:404-418. doi:10.1016/j.jue.2009.11.006

Graham-Rowe D (2010) Are vertical farms the future of urban food? The Guardian, 29 July 2010, United Kingdom

Grewal SS, Grewal PS (2012) Can cities become self-reliant in food? Cities 29:1-11

GSCC, Coomes Consulting (2006) Greater Shepparton 2030 strategy plan. Coomes Consulting Group, Shepparton, Victoria

GVPCP (2011) Goulburn Valley community profile. Goulburn Valley Primary Care Partnership http://gvpcp.org.au/index.php?option= com_docman\&task $=$ cat_view\&gid $=44 \& I$ temid $=68$. Accessed 26 March 2012

Hamilton AJ, Burry K, Mok H-F, Barker F, Grove JR, Williamson VG (2013) Give peas a chance? Urban agriculture in developing countries. A review. Agron Sustain Dev. doi:10.1007/s13593013-0155-8

Hamilton AJ, Stagnitti F, Xiong X, Kreidl SL, Benke KK, Maher P (2007) Wastewater irrigation: the state of play. Vadose Zone $\mathrm{J}$ 6:823-840. doi:10.2136/vzj2007.0026

Hering I (1995) Gardens that nourish a community. Whitehorse Gazette, Melbourne

Hough RL, Breward N, Young SD, Crout NMJ, Tye AM, Moir AM, Thornton I (2004) Assessing potential risk of heavy metal exposure from consumption of home-produced vegetables by urban populations. Environ Health Perspect 112:215-221. doi:10.1289/ehp.5589

Houston P (2005) Re-valuing the fringe: some findings on the value of agricultural production in Australia's peri-urban regions. Geogr Res 43:209-223. doi:10.1111/j.1745-5871.2005.00314.x 
Humphery K (1998) Shelf life: supermarkets and the changing cultures of consumption. Cambridge University Press, Melbourne

Hynes H, Howe G (2004) Urban horticulture in the contemporary United States: personal and community benefits. Acta Hortic 643:171-181

Ichikawa K, Okubo N, Okubo S, Takeuchi K (2006) Transition of the Satoyama landscape in the urban fringe of the Tokyo metropolitan area from 1880 to 2001. Landsc Urban Plann 78:398-410. doi:10.1016/j.landurbplan.2005.12.001

Ikeda M, Ezaki T, Tsukahara T, Moriguchi J (2004) Dietary cadmium intake in polluted and non-polluted areas in Japan in the past and in the present. Int Arch Occup Environ Health 77:227-234. doi:10.1007/s00420-003-0499-5

Ikeda M, Shimbo S, Watanabe T, Yamagami T (2006) Correlation among cadmium levels in river sediment, in rice, in daily foods and in urine of residents in 11 prefectures in Japan. Int Arch Occup Environ Health 79:365-370. doi:10.1007/s00420-005-0069-0

Ikeda M, Zhang ZW, Shimbo S, Watanabe T, Nakatsuka H, Moon CS, Matsuda-Inoguchi N, Higashikawa K (2000) Urban population exposure to lead and cadmium in East and South-east Asia. Sci Total Environ 249(1-3):373-384. doi:10.1016/s0048-9697(99) 00527-6

Imamura T, Ide H, Yasunaga $H$ (2007) History of public health crises in Japan. J Pub Health Pol 28:221-237. doi:10.1057/ palgrave.jphp.3200131

Iwafune T, Yokoyama A, Nagai T, Horio T (2011) Evaluation of the risk of mixtures of paddy insecticides and their transformation of products to aquatic organisms in the Sakura River. Japan Environ Toxicol Chem 30(8):1834-1842. doi:10.1002/etc.569

Jacke D, Toensmeier E (2005) Edible forest gardens. Chelsea Green Publishing, White River Junction

Japan Ministry of Health Labour and Welfare (2012) Imported foods inspection service. Japan Ministry of Health, Labour, and Welfare. http://www.mhlw.go.jp/english/topics/importedfoods/. Accessed 25 May 2012

Johnston J, Baker L (2005) Eating outside the box: foodshare's good food box and the challenge of scale. Agric Hum Val 22:313-325

Jones A (2002) An environmental assessment of food supply chains: a case study on dessert apples. Environ Manage 30:560-576. doi:10.1007/s00267-002-2383-6

Kachenko A, Singh B (2006) Heavy metals contamination in vegetables grown in urban and metal smelter contaminated sites in Australia. Wat Air S Pollut 169:101-123. doi:10.1007/s11270006-2027-1

Kamoshita A (2007) Historical changes in urban rice production systems in Tokyo, Japan. P1 Prod Sci 10:245-269. doi:10.1626/ pps. 10.245

Kawahara J, Horikoshi R, Yamaguchi T, Kumagai K, Yanagisawa Y (2005) Air pollution and young children's inhalation exposure to organophosphorus pesticide in an agricultural community in Japan. Environ Int 31:1123-1132. doi:10.1016/j.envint.2005.04.001

Kenner R (2008) Food, Inc. Magnolia Pictures, United States, $94 \mathrm{~min}$

Kieninger PR, Yamaji E, Penker M (2011) Urban people as paddy farmers: the Japanese Tanada ownership system discussed from a European perspective. Renew Agric F Syst 26:328-341. doi:10.1017/s1742170511000123

Kimura AH (2011) Nationalism, patriarchy, and moralism: the government-led food reform in contemporary Japan. F Foodw Explorat Hist Cultu Hum Nourish 19:201-227

Kimura AH, Nishiyama M (2008) The chisan-chisho movement: Japanese local food movement and its challenges. Agric Human Values 25(1):49-64. doi:10.1007/s10460-007-9077-x

Kingsley J, Townsend M (2006) 'Dig in' to social capital: community gardens as mechanisms for growing urban social connectedness. Urban Pol Res 24(4):525-537
Kitahara E (2003) The direction of rural development policies in Japan. In: Organisation for Economic Co-operation and Development (ed) Future of rural policy: from sectoral to place-based policies in rural areas. OECD Publishing, Paris, pp 61-75

Kitchen Garden Foundation (2012) The Stephanie Alexander Kitchen Garden Foundation. http://www.kitchengardenfoundation.org.au/. Accessed 6 June 2012

Knowd I, Mason D, Docking A (2006) Urban agriculture: the new frontier. Planning for Food Seminar, 21 June 2006, Vancouver, Canada

Kortright R, Wakefield S (2011) Edible backyards: a qualitative study of household food growing and its contributions to food security. Agric Hum Val 28:39-53. doi:10.1007/s10460-009-9254-1

Kretschmer F, Kollenberg ME (2011) Vertical farming: can urban agriculture feed a hungry world? Spiegel, 22 July 2011

Kumazawa K (2002) Nitrogen fertilization and nitrate pollution in groundwater in Japan: present status and measures for sustainable agriculture. Nutr Cycl Agroecosys 63:129-137. doi:10.1023/ a: 1021198721003

Kurita H, Yokohari M, Bolthouse J (2009) The potential of intra-regional supply and demand of agricultural products in an urban fringe area: a case study of the Kanto Plain, Japan. Geografisk Tidsskrift-Danish J Geog 109:147-159

Lai HY, Chen ZS (2004) Effects of EDTA on solubility of cadmium, zinc, and lead and their uptake by rainbow pink and vetiver grass. Chemos 55:421-430. doi:10.1016/j.chemosphere.2003.11.009

Landshare (2012) Landshare: connecting growers to people with land to share. http://www.landshare.net/about/. Accessed 30 June 2012

Larsen K, Ryan C, Abraham AB (2008) Sustainable and secure food systems for Victoria: what do we know? What do we need to know? Victorian Eco-Innovation Lab, Australian Centre for Science Innovation and Society, University of Melbourne, Melbourne, Australia

Larson NI, Story MT, Nelson MC (2009) Neighborhood environments disparities in access to healthy foods in the US. Am J Prev Med 36:74-81. doi:10.1016/j.amepre.2008.09.025

Lasat MM (2002) Phytoextraction of toxic metals: a review of biological mechanisms. J Environ Qual 31:109-120

Lee S, Mohai P (2011) Research article: racial and socioeconomic assessments of neighborhoods adjacent to small-scale brownfield sites in the Detroit region. Environ Prac 13:340-353

Let's Move (2012) Let's move: America's move to raise a healthier generation of kids. http://www.letsmove.gov/. Accessed 20 June 2012

Litt JS, Burke TA (2002) Uncovering the historic environmental hazards of urban brownfields. J Urb Health 79:464-481

Living Victoria Ministerial Advisory Council (2012) Living Melbourne, living Victoria. Implementation plan. Department of Sustainability and Environment, Living Victoria Ministerial Advisory Council, Melbourne, Australia

Lobao L, Meyer K (2001) The great agricultural transition: crisis, change, and social consequences of twentieth century US farming. Annu Rev Sociol 27:103-124. doi:10.1146/annurev.soc.27.1.103

London Assembly (2010) Cultivating the capital: food growing and the planning system in London. Planning and Housing Committee, London, UK

Low Choy D, Sutherland C, Gleeson B, Sipe N, Dodson J (2008) Change and continuity in peri-urban Australia: peri-urban futures and sustainable development. Griffith University, Brisbane, Queensland

MAFF (2006) What is "shokuiku" (food education)? Ministry of Agriculture, Forestry, and Fisheries, Tokyo, Japan

Mah CL (2010) Shokuiku: governing food and public health in contemporary Japan. J Sociol Chengchi 46:393-412

Malakoff D (2004) Final harvest: community greening review. American Community Gardening Association. http://communitygarden.org/ docs/learn/articles/whatgoodiscommunitygreening.pdf. Accessed 9 September 2011 
Mapanda F, Mangwayana EN, Nyamangara J, Giller KE (2005) The effect of long-term irrigation using wastewater on heavy metal contents of soils under vegetables in Harare, Zimbabwe. Agric Ecosyst Environ 107:151-165. doi:10.1016/j.agee.2004.11.005

Marris E (2010) The vertical farm: feeding the world in the 21st century. Nature 468:374-374. doi:10.1038/468374a

Mason D, Knowd I (2010) The emergence of urban agriculture: Sydney, Australia. Int J Agron Sust 8(1-2):62-71. doi:10.3763/ijas.2009.0474

Mayor of London (2004) The London plan: spatial development strategy for Greater London. Greater London Authority, London, UK

Mayor of London (2006) Healthy and sustainable food for London: the mayor's food strategy. London Development Agency, London, $\mathrm{UK}$

Mayor of London (2011) The London plan: spatial development strategy for Greater London. Greater London Authority, London, UK

McWilliams JE (2009) Just food: how locavores are endangering the future of food and how we can truly eat responsibly. Little, Brown, and Company, New York

Mentens J, Raes D, Hermy M (2006) Green roofs as a tool for solving the rainwater runoff problem in the urbanized 21 st century? Landscape Urban Plann 77(3):217-226. doi:10.1016/ j.landurbplan.2005.02.010

Merrick J, Hickman M (2011) IoS campaign buries plan to close allotments. The Independent, 08 May 2011. London, UK

Merrick J, Jewsbury M (2011) Exclusive: the end of the good life. The Independent, 01 May 2011, London, UK

Millar J, Roots J (2012) Changes in Australian agriculture and land use: implications for future food security. Int J Agron Sust 10:2539. doi:10.1080/14735903.2012.646731

Millar R, Fyfe M (2012a) The fertile fringe. The Age, 26 May 2012, Melbourne, Victoria

Millar R, Fyfe M (2012b) Food from somewhere. The Age, 11 June 2012, Melbourne, Victoria

Miyoshi M, Tsuboyama-Kasaoka N, Nishi N (2012) School-based "shokuiku" program in Japan: application to nutrition education in Asian countries. Asia Pac J Clin Nutr 21:159-162

Mok H-F, Majumder R, Laidlaw WS, Gregory D, Baker AJM, Arndt SK (2013) Native Australian species are effective in extracting multiple heavy metals from biosolids. Int J Phytoremediat 15(7):615-632. doi:10.1080/15226514.2012.723063

Mollison B, Holmgren D (1978) Permaculture 1: A perennial agricultural system for human settlements. Corgi Publications, Melbourne

Morris D (1987) Healthy cities: self-reliant cities. Health Promot 2:169-176

Mougeot LJA (2000) Urban agriculture: definition, presence, potentials and risks. In: Bakker N, Dubbeling M, Guendel S, Sabel Koschella U, de Zeeuw $\mathrm{H}$ (eds) Growing cities, growing food, urban agriculture on the policy agenda. German Foundation for International Development, Feldafing, Germany, pp 1-42

Müller B (2007) Food miles or poverty eradication? The moral duty to eat African strawberries at Christmas. Oxford Institute for Energy Studies, United Kingdom

Munn J, January M, Cutright TJ (2008) Greenhouse evaluation of EDTA effectiveness at enhancing $\mathrm{Cd}, \mathrm{Cr}$, and $\mathrm{Ni}$ uptake in Helianthus annuus and Thlaspi caerulescens. J Soils Sed 8:116122. doi: $10.1065 /$ jss 2008.02 .274

Munroe-Santos S (1998) National community gardening survey: 1996. American Community Gardening Association

Nakai N (1988) Urbanization promotion and control in metropolitan Japan. Plan Perspect 3:197-216

Nasr J, MacRae R, Kuhns J (2010) Scaling up urban agriculture in Toronto: building the infrastructure. Metcalf Foundation, Toronto

NSALG, APU (1997) National allotment survey. National Association of Allotment and Leisure Gardens, Anglia Polytechnic University, London, UK
Oberndorfer E, Lundholm J, Bass B, Coffman RR, Doshi H, Dunnett N, Gaffin S, Kohler M, Liu KKY, Rowe B (2007) Green roofs as urban ecosystems: ecological structures, functions, and services. Bioscience 57:823-833. doi:10.1641/b571005

Okamura H, Piao M, Aoyama I, Sudo M, Okubo T, Nakamura M (2002) Algal growth inhibition by river water pollutants in the agricultural area around Lake Biwa. Japan Environ Pollut 117:411-419

Okvat HA, Zautra AJ (2011) Community gardening: a parsimonious path to individual, community, and environmental resilience. Am J Community Psychol 47:374-387. doi:10.1007/s10464-010-9404-z

Pack C (1919) The war garden victorious. J.B. Lippincott, Philadelphia

Paxton A (1994) The food miles report - the dangers of long-distance food transport. Sustainable Agriculture Food and Environment Alliance, London, UK

Pearson LJ, Pearson L, Pearson CJ (2010) Sustainable urban agriculture: stocktake and opportunities. Int J Agron Sust 8:7-19. doi:10.3763/ ijas. 2009.0468

People's Food Policy Project (2011) Resetting the table: a people's food policy for Canada. People's Food Policy Project, Toronto

Peralta-Videa JR, Lopez ML, Narayan M, Saupe G, Gardea-Torresdey J (2009) The biochemistry of environmental heavy metal uptake by plants: implications for the food chain. Int J Biochem Cell Biol 41:1665-1677. doi:10.1016/j.biocel.2009.03.005

Permaculture Global (2012) Worldwide permaculture projects. http:// www.permacultureglobal.com/projects. Accessed 8 June 2012

Perren R (2005) Farmers and consumers under strain: Allied meat supplies in the First World War. Agric History Rev 53:212-228

Pilon-Smits E (2005) Phytoremediation. Annu Rev Plant Biol 56:1539. doi:10.1146/annurev.arplant.56.032604.144214

Plassmann K, Norton A, Attarzadeh N, Jensen MP, Brenton P, Edwards-Jones G (2010) Methodological complexities of product carbon footprinting: a sensitivity analysis of key variables in a developing country context. Environ Sci Policy 13:393-404. doi:10.1016/j.envsci.2010.03.013

PMSEIC (2010) Australia and food security in a changing world. The Prime Minister Engineering and Innovation Council, Canberra, Australia

Pollan M (2006) The omnivore's dilemma: a natural history of four meals. Penguin, New York

Prasad MNV, Freitas HMD (2003) Metal hyperaccumulation in plants - biodiversity prospecting for phytoremediation technology. Electron J Biotechnol 6:285-321

Press M, Arnould E (2011) Legitimating community supported agriculture through American pastoralist ideology. J Consum Cult 11:168-194

Radcliffe JC (2010) Evolution of water recycling in Australian cities since 2003. Water Sci Technol 62:792-802. doi:10.2166/ wst. 2010.362

Rama I, Lawrence P (2008) Food miles - a critical evaluation. Connections Paper No. 29, University of Melbourne Agribusiness Journal

Reading Agricultural Consultants (2003) Study of the horticultural glasshouse industry in Epping Forest District. Reading Agricultural Consultants Ltd. in association with Gerry Hayman and Hennock Industries Ltd., Races Farm, Aston Tirrold, Oxfordshire

Rebitzer G, Ekvall T, Frischknecht R, Hunkeler D, Norris G, Rydberg T, Schmidt WP, Suh S, Weidema BP, Pennington DW (2004) Life cycle assessment: part 1: Framework, goal and scope definition, inventory analysis, and applications. Environ Int 30:701-720. doi:10.1016/j.envint.2003.11.005

Saldivar-Tanaka L, Krasny ME (2004) Culturing community development, neighborhood open space, and civic agriculture: the case of Latino community gardens in New York City. Agric Human Values 21:399-412. doi:10.1023/B:AHUM. 0000047207.57128.a5

Saumel I, Kotsyuk I, Holscher M, Lenkereit C, Weber F, Kowarik I (2012) How healthy is urban horticulture in high traffic areas? Trace metal concentrations in vegetable crops from plantings 
within inner city neighbourhoods in Berlin, Germany. Environ Pollut 165:124-132. doi:10.1016/j.envpol.2012.02.019

Saunders C, Barber A (2008) Carbon footprints, life cycle analysis, food miles: global trade trends and market issues. Polit Sci 60:73-88

Saunders C, Barber A, Taylor G (2006) Food miles-comparative energy/emissions performance of New Zealand's agriculture industry. Agribusiness and Economics Research Unit (AERU), Lincoln University, Lincoln, New Zealand

Saunders P (1993) Allotment gardeners in England and Wales: report of a national sample survey. National Society of Allotment and Leisure Gardeners Ltd, Corby, UK

SBS (2010) Food shortage 'the next global challenge'. SBS News. http://www.sbs.com.au/news/article/1214782/Food-shortage-thenext-global-challenge-. Accessed 25 May 2012

Schafft KA, Jensen EB, Hinrichs CC (2009) Food deserts and overweight schoolchildren: evidence from Pennsylvania. Rural Sociol 74:153-177

Scherr SJ, McNeely JA (2008) Biodiversity conservation and agricultural sustainability: towards a new paradigm of 'ecoagriculture' landscapes. Philos Trans R Soc B Biol Sci 363:477-494

Schlenker W, Roberts MJ (2009) Nonlinear temperature effects indicate severe damages to US crop yields under climate change. Proc Natl Acad Sci U S A 106:15594-15598

Schlosser E (2001) Fast food nation: the dark side of the all-American meal. Houghton Mifflin Harcourt, New York

Sebastian R, Wilkinson Enns C, Goldman J (2011) MyPyramid intakes and snacking patterns of US adults: what we eat in America. NHANES 2007-2008, Dietary Data Brief No. 5. United States Department of Agriculture, Agricultural Research Service, Food Surveys Research Group

Senesi GS, Baldassarre G, Senesi N, Radina B (1999) Trace element inputs into soils by anthropogenic activities and implications for human health. Chemosphere 39:343-377. doi:10.1016/s00456535(99)00115-0

Shaw HJ (2006) Food deserts: towards the development of a classification. Geogr Ann Ser B-Hum Geogr 88B:231-247. doi:10.1111/j.04353684.2006.00217.x

Sinclair MI, O'Toole J, Malawaraarachchi M, Leder K, Barker F, Hamilton AJ (2011) Greywater use in the backyard: what are the health risks? Final report to the Smart Water Fund. Monash University and The University of Melbourne, Melbourne, Australia

Slater RJ (2001) Urban agriculture, gender and empowerment: an alternative view. Devel Southern Africa 18:635-650. doi:10.1080/03768350120097478

Smit J, Ratta A, Nasr J (1996) Urban agriculture: food, jobs and sustainable cities. UNDP, New York

Sorensen A (2000) Land readjustment and metropolitan growth: an examination of suburban land development and urban sprawl in the Tokyo metropolitan area. Prog Plan 53:217-330

The Age (2012) Foolish planning forgets about food. The Age, 26 May 2012

Theodosiou TG (2003) Summer period analysis of the performance of a planted roof as a passive cooling technique. Energy Buildings 35:909-917. doi:10.1016/s0378-7788(03)00023-9

Timmons D, Wang Q (2010) Direct food sales in the United States: evidence from state and county-level data. J Sust Agric 34(2):229-240

Tsukahara T, Ezaki T, Moriguchi J, Furuki K, Shimbo S, Matsuda-Inoguchi N, Ikeda M (2003) Rice as the most influential source of cadmium intake among general Japanese population. Sci Total Environ 305(1-3):41-51. doi:10.1016/ s0048-9697(02)00475-8

Turner B (2011) Embodied connections: sustainability, food systems and community gardens. Local Environ 16:509-522

Twiss J, Dickinson J, Duma S, Kleinman T, Paulsen H, Rilveria L (2003) Community gardens: lessons learned from California healthy cities and communities. Am J Public Health 93:14351438. doi:10.2105/ajph.93.9.1435

UN Population Division (2005) World urbanization prospects: the 2005 revision. United Nations Department of Economic and Social Affairs, Population Division, New York

Urban Ecological Systems (2007). http://urbanecologicalsystems.com/. Accessed 06 June 2012

US Census Bureau (2010) Current population reports p60-239income, poverty and health insurance in the United States: 2010. United States Census Bureau, United States Department of Commerce, Washington, DC

US EPA (2011) Brownfields and urban agriculture: interim guidelines on safe gardening practices. United States Environmental Protection Agency, Chicago, IL

USDA (2009) 2007 census of agriculture. United States Department of Agriculture, National Agricultural Statistics Service, Washington, DC

USDA (2010) The people's garden initiative. United States Department of Agriculture, Washington, DC

USDA (2012) Know your farmer, know your food. United States Department of Agriculture. http://www.usda.gov/wps/portal/usda/ usdahome?navid=KNOWYOURFARMER. Accessed 14 June 2012

VanWoert ND, Rowe DB, Andresen JA, Rugh CL, Fernandez RT, Xiao L (2005) Green roof stormwater retention: effects of roof surface, slope, and media depth. J Environ Qual 34:1036-1044. doi: $10.2134 /$ jeq2004.0364

Venkataraman B (2008) Country, the city version: farms in the sky gain new interest. New York Times, 15 July 2008

Vertical Farm (2012) The vertical farm. www.verticalfarm.com. Accessed 06 June 2012

Walker RE, Keane CR, Burke JG (2010) Disparities and access to healthy food in the United States: a review of food deserts literature. Health Place 16:876-884. doi:10.1016/j.healthplace.2010.04.013

Walter GH (2003) Insect management and ecological research. Cambridge University Press, Cambridge, UK

Watanabe T, Shimbo S, Moon CS, Zhang ZW, Ikeda M (1996) Cadmium contents in rice samples from various areas in the world. Sci Total Environ 184:191-196. doi:10.1016/0048-9697(96)05100-5

Weber CL, Matthews HS (2008) Food-miles and the relative climate impacts of food choices in the United States. Environ Sci Technol 42:3508-3513

Wiltshire R, Azuma R (2000) Rewriting the plot: sustaining allotments in the UK and Japan. Local Environ 5:139-151

Wimberley R, Fulkerson G, Morris L (2007) Predicting a moving target. Rural Sociol 28:18-22

Wong NH, Chen Y, Ong CL, Sia A (2003) Investigation of thermal benefits of rooftop garden in the tropical environment. Build Environ 38:261-270. doi:10.1016/s0360-1323(02)00066-5

World Bank (2012) Country and lending groups. http:// data.worldbank.org/about/country-classifications/country-andlending-groups. Accessed 14 June 2012

Wright AR (1942) Food purchases of the Allies, 1917-1918. Agricul History 16:97-102

Wuana RA, Okieimen FE (2011) Heavy metals in contaminated soils: a review of sources, chemistry, risks and best available strategies for remediation. ISRN Ecology 2011 (Article ID 402647):20. doi: $10.5402 / 2011 / 402647$

Yokohari M, Amati M, Bolthouse J, Kurita H (2010) Restoring agricultural landscapes in shrinking cities: re-inventing traditional concepts in Japanese planning. In: Primdahl J, Swaffield S (eds) Globalisation and agricultural landscapes change patterns and policy trends in developed countries. Cambridge University Press, Cambridge, UK, pp 225-244

Yokohari M, Takeuchi K, Watanabe T, Yokota S (2000) Beyond greenbelts and zoning: a new planning concept for the environment of Asian mega-cities. Landscape Urban Plann 47(3-4):159-171. doi:10.1016/s0169-2046(99)00084-5 